\title{
CERCETĂRI INTERDISCIPLINARE ÎN TELL-UL DE LA VÂNĂTORII MICI MOMÂAI (JUD. GIURGIU, ROMÂNIA)
}

\author{
CÃTĂLIN BEM, ANDREI ASĂNDULESEI, CONSTANTIN HAITĂ, CARMEN BEM, VASILE OPRIŞ
}

\author{
INTERDISCIPLINARY RESEARCHES ON THE TELL FROM \\ VÂNĀTORII MICI MOMÂIA (GIURGIU COUNTY, ROMANIA)
}

We claim once again the fact that the sustainability of a scientific project refers also to the extent to which the Consortium - in our case formed by the National Museum of Romanian History, as coordinator and the "Alexandru Ioan Cuza" University Iaşi represented by the Arheolnvest platform - established to implement the CHRONOS Project, is able to carry the same scientific approaches after the end of the financed project. It should be noted in addition that this Consortium is the originator of widely non-intrusive research in SouthCarpathian area. It is for the first time when based on a consistent methodology, developed, evaluated and implemented successfully, it was undertaken the non-destructive investigation of multilayered Gumelniţa's settlements, of the hinterland and their contemporary landscape.

The tell from Vânătorii Mici Momâia (Giurgiu County) is one of the investigated sites. For nondestructive evaluation of the site were used 3D scanning, oblique aerial photographs, magnetometric scanning and the stratigraphic coring survey.

Interdisciplinary analysis of the data obtained showed the existence of a delimiting ditch of the tell, dug at the base of the mound in the floodplain. As in other cases, stratigraphic corings revealed the presence of a "barrier" between the ditch and the effective inhabited area (framed clearly in an area of approximately 210 sq.m.). No matter what might be named (dike, dam, etc.) this covers a large area (usually $7.5-8 \mathrm{~m}$ wide), but with a relatively low height (less than $1 \mathrm{~m}$ in all similar cases).

The fact that all other small and medium sized tell sites investigated by CHRONOS team presented the same way of construction - ditch boundary, dike/dam, the actual residential area, itself firmly bounded (with palisades fixed in foundation trenches, as demonstrated by archaeological excavations), leads us to the conclusion that this is the model of the general internal structure of all these settlements.

KEYWORDS: Chalcolithic, Gumelniła tell, 3D laser scanning, stratigraphic corings, aerial photogrammetry, magnetometry, delimitation ditch, dike

CUVINTE CHEIE: calcolitic, tell Gumelniţa, carotaje stratigrafice, aerofotogrametrie, magnetometrie, elemente de delimitare

PREMISE

Multitudinea de situri eneolitice investigate majoritar neintruziv în cadrul Proiectului CHRONOS $^{1}$ ne-a permis formularea unor concluzii ${ }^{2}$, unele cu caracter punctual, altele cu valoare generalizatoare.

Important de amintit aici este că sustenabilitatea unui proiect ştiinţific se referă şi la măsura în care Consortiul - în cazul nostru având ca piloni principali Muzeul Naţional de Istorie a României (MNIR) şi Universitatea „Alexandru Ioan Cuza” Iaşi, prin Platforma ArheoInvest - înfiinţat pentru implementarea unui proiect, este capabil să desfăşoare aceleaşi demersuri ştiinţifice şi după încheierea respectivei finanţări. Trebuie menţionat în plus că acest Consorţiu este iniţiatorul cercetărilor

\footnotetext{
1 Această intervenție utilizează informaţii obţinute şi în urma implementării (2008-2011) proiectului CHRONOS. Acesta a avut ca scop şi conturarea unui model de cercetare nedistructivă a tell-urilor Gumelniţa. Aşa cum afirmam şi cu alte ocazii, două dintre obiectivele sale principale au fost decelarea distribuţiei spaţiale şi temporale a tuturor staţiunilor Gumelniţa în spaţiul actual al României, implicând şi modul de formare a tell-urilor, precum şi identificarea unor probabile modele de locuire.

${ }^{2}$ Bem et alii 2010a; Bem et alii 2010b; Bem et alii 2012; Bem et alii 2013; Bem et alii 2014
} 
neintruzive pe scară largă în spaţiul sud-carpatic. Este pentru prima dată când, pe baza unei metodologii coerente, elaborată, evaluată şi implementată cu succes, s-a procedat la investigarea nedistructivă a staţiunilor pluristratificate Gumelniţa, a hinterland-ului acestora şi a peisajului lor contemporan.

Primele etape de teren ale investigaţiilor subsumate proiectului $C H R O N O S^{3}$, in conformitate cu propriile principii metodologice, au vizat strict evaluarea gradului de confirmare a informaţiile bibliografice în teren - identificarea fizică a siturilor doar menţionate bibliografic şi, firesc, compararea informaţiilor (de exemplu, de natură dimensională şi geomorfologică) cu situația existentă în teren.

Alegerea zonei comunei Vânătorii $\mathrm{Mici}^{4}$ (jud. Giurgiu) (PI. I) a avut o serie de rațiuni. În primul rând, erau amintite două tell-uri ${ }^{5}$, unul sondat, celălalt doar menționat. În plus, erau amplasate la $N$ de microzona Bucșani, binecunoscutã nouă ${ }^{6}$, și puteau constitui o bază pentru viitoarele investigaţii. În al doilea rând, după indicațiile bibliografice, dimensiunile ambelor situri erau mici ambele nedepășind $2,50 \mathrm{~m}$ înălțime și având numai 40 și, respectiv, $60 \mathrm{~m}$ ca diametru - ceea ce putea constitui un impediment în identificarea lor. Mai mult, cercetarea arheologică s-a petrecut în anii 1972-1973, trecând suficient de mult timp pentru ca o intervenție din exterior să se şteargă din memoria comunităților locale. Ceea ce am presupus s-a şi adeverit, neobținând nici o informație de la localnici despre o eventuală săpătură arheologică autorizată în zonă.

Evident, etapa de teren a fost precedată de consultarea puţinelor informații bibliografice, dar şi de cercetări cartografice, utilizând planuri de 1:25000 și 1:5000, de vizualizări ale ortofotoplanurilor și ale fotografiilor satelitare. Pe nici una dintre aceste ultime surse utilizate nu s-au remarcat cele două staţiuni. Așadar, identificarea lor rămânea exclusiv în sarcina investigației de teren, îngreunată - aşa cum am constatat ulterior - de faptul că schița publicată $\breve{a}^{7}$ nu era construită la scară - distanţa dintre cele două situri, indusă de schiță, este de $1,35 \mathrm{~km}$, în realitate fiind de aproximativ $3,1 \mathrm{~km}$ (în linie dreaptă).

În unica sursă bibliografică nu se regăseşte nici un toponim local. Cel dintâi tell ${ }^{8}$ este amplasat în limita administrativă a satului Vânătorii Mici, fiind numit de către localnici Momâia ${ }^{9}$, cel de-al doilea $^{10}$, în zona cunoscută în toponimia locală sub denumirea de Burta Vacii ${ }^{11}$, în satul Izvoru. Mai mult, dimensiunile indicate de bibliografie ${ }^{12}$ sunt mai mici decât cele reale.

Paradoxal, tell-ul sondat în 1972-1973 (Vânătorii Mici Momâia) - la care ne vom referi mai în detaliu în această intervenţie, nu este reţinut în lista monumentelor istorice, dar nici măcar în Repertoriul Arheologic Nał̧ional. În schimb, cel de la Izvoru Burta Vacii beneficiază de dubla protecţie a legii - are codul RAN 106014.01 (cu toponimul Spital ${ }^{13} \ldots$..) şi cel LMI 2004GR-I-s-B14798. Nu este nici prima, nici ultima omisiune.

Staţiunea este amplasată în lunca Neajlovului, pe malul său stâng (PI. I/2), într-o zonă cu numeroase izvoare, în apropierea terasei, la aproximativ $600 \mathrm{~m} \mathrm{~S}$ de biserica satului. Are o înălțime de $3,80 \mathrm{~m}$ şi diametrele de $70 \times 80 \mathrm{~m}(\mathbf{P l}$. II/4) - precizări obţinute din propria ridicare topografică.

\footnotetext{
${ }^{3}$ Pentru zona dobrogeană, de exemplu, Bem 2011 a şi Bem 201 lb.

${ }^{4}$ La identificarea primară au participat şi domnii Eugen Paraschiv şi Emil Dumitrașcu, membri ai echipei CHRONOS din partea MNIR.

${ }^{5}$ Trohani, Oancea 1976

${ }^{6}$ Vezi Bem 2007 cu bibliografia.

${ }^{7}$ Trohani, Oancea 1976, fig. I

${ }^{8}$ Trohani, Oancea 1976, fig. 1/2

${ }^{9}$ Toponimul este relativ frecvent în zona de nord-est a fostului judet Vlaşca şi se referă la movile de pământ - fără îndoialā, tell-uri - din luncile râurilor. În restul Vlaşcăi toponimul corespondent este majoritar cel de Măgură.

${ }^{10}$ Trohani, Oancea 1976, fig. 1/1

11 Toponimul în sine se referã la spaţiul mlăştinos din jurul tell-ul, alimentat de mici izvoare.

12 Fără a avea legătură cu lipsurile bibliografice, nici starea de conservare nu concordă întrutotul. Într-o Românie în care monumentele istorice sau siturile reperate nu reprezintă o prioritate nici pentru autorități, nici pentru comunități locale, nu ne mai miră acest fapt. Devine evident că starea de conservare a siturilor era mult mai bună la începutul anilor '70 ai secolului trecut. Practic, în acest moment, exceptând siturile aflate în curs de cercetare, pentru care există ridicări topografice şi măsurători exacte, ar trebui să privim cu circumspecție o mare parte a informațiilor bibliografice. Numai etapele de teren pot defini o serie importantă de aspecte, inclusiv de natură dimensională.

${ }^{13}$ Conac boieresc din secolul al XIX-lea (PI. II/3), fost sediu CAP, astăzi spital de penumoftiziologie, extrem de degradat, el însuşi monument istoric (GR-II-m-B-15025).
} 
Scanarea magnetometrică a relevat existenţa unui şanţ de delimitare săpat la nivelul luncii ${ }^{14}$. Pe o mare parte a suprafeţei sale au fost plantał̧i pomi fructiferi - terenul fiind dat în posesie/folosinţă - și au fost întreprinse săpături clandestine de amploare (vizibile şi pe harta scanării magnetometrice) - de către localnici ${ }^{15}$.

Tell-ul de la Vânătorii Mici Momâia este amplasat, de asemenea, în lunca Neajlovului, la cca. $30 \mathrm{~m}$ vest de actualul curs al râului, în zona confluenţei Văii Baracu cu acesta (Pl. I/2, V/1). Se află în apropierea terasei dreapta (Pl. II/5, IV/1,V/1) și la aproximativ $900 \mathrm{~m} \mathrm{~N}$-NV de şcoala din satul Corbeanca şi la $600 \mathrm{~m} \mathrm{~S}-\mathrm{SV}$ de biserica satului Vânătorii Mici. Zona din proximitatea sitului este străbătută de o serie de mici cursuri intermitente de apă (PI. IV, V/1), reactivate de precipitał̧ii şi revărsările Neajlovului. Este foarte probabil ca cel mai important dintre aceste cursuri de apă să reprezinte, în fapt, un fost meandru al râului (PI. IV). Acest aspect nu exclude ca toate cursurile să fi fost meandre ale râului, care are un evident caracter migrator.

Deşi nu foarte detaliată, harta Szathmári (1864) reţine o serie de bălți, naturale dar, probabil, şi artificiale $^{16}$ în zona celor două tell-uri (PI. II/1). În plus, Valea Baracu, fără a părea a fi activă, este figurată.

Din păcate, o mare parte din suprafał̧a tell-ului este arată (PI. IL/5, IV) și, cel puțin pentru nivelurile superioare, stratigrafia este afectată ireversibil. Situaţia a devenit extrem de frecventă în sudul României, numeroase staţiuni similare fiind, astfel, în mod continuu degradate, deşi marea majoritate este inclusă în Lista Monumentelor Istorice.

Sumarele cercetări arheologice de la începutul anilor '70 ai secolului trecut, realizate printr-o secţiune magistrală orientată aproximativ E-V, au relevat existenţa mai multor etape de locuire, aparţinând primelor două faze Gumelniţa ${ }^{17}$. Materialul arheologic publicat (PI. III) sau nu ${ }^{18}$, dar şi cel recuperat de noi, pare să confirme aceste încadrări. În plus, prezenţa unor fragmente ceramice decorate prin excizii foarte largi sau cu motivul labirintului - elemente specifice fazei Gumelnița Bl - poate indica faptul că cel puţin nivelul superior (incendiat, după cum vom arăta mai jos) se încadrează în ultima fază Gumelniţa. Fenomenul este general în bazinul mijlociu al Neajlovului ${ }^{19}$, şi nu este cazul să detaliem aici. Trebuie menţionat însă, că, niciodată, simpla prezenţă a unui fragment ceramic nu este determinantă pentru încadrarea cu certitudine în vreuna din fazele amintite.

\section{METODOLOGIE}

Cercetările de teren succesive au urmărit în primul rând identificarea unor eventuale locuiri Gumelniţa exterioare - sezoniere, temporare sau de lungă durată, în măsura în care ele erau fizic decelabile în peisaj. Interesul s-a axat mai cu seamă în aria de vizibilitate, cu o rază de $5 \mathrm{~km}$ (corespunzând vizibilităţii nivelului superior şi în condiţii de vegetaţie de luncă) (Pl. II/2), neomiţând, evident, celelalte spaţii. Cercetārile de teren nu au condus decât la reidentificarea unor staţiuni menţionate anterior ${ }^{20}$, din epoci ulterioare. De altfel, modelul de locuire gumelniţean, în cazul tell-

\footnotetext{
14 Din păcate, încercarea noastră de a realiza carotaje stratigrafice pentru verificarea scanării magnetometrice a fost zădămicită de nivelul extrem de ridicat al pânzei freatice.

${ }^{15}$ Informaţii obţinute de la persoana pusă în posesia terenului de către Primăria Vânătorii Mici.

${ }^{16}$ Simbolul *, deşi nu apare în legenda hărţii (www.chartal 864.ro/images/legend.jpg), corespunde foarte probabil unor mori de apā.

17 Trohani, Oancea 1976, 19. Foarte probabil, au fost realizate atunci şi o serie de casete, vizibile şi astăzi. Nu este exclus, însă, ca unelc dintre aceste intervenţii să corespundă unora neștiinţifice, practicate de localnici.

${ }^{18}$ MNIR nr. inv. 83.816-83.857, 291.167-291.170

19 Ambele tell-uri în curs de cercetare de la Bucşani (situate la $14-15 \mathrm{~km}$ sud de zona noastră de interes), amintite, includ niveluri Gumelniţa Bl. Aceeaşi menţiune este valabilă şi în cazul tell-urilor de la Corbii Mari Măgura (Olteanu 2002, 88 și urm.) sau Moara din Groapă Măgura (ambele com. Corbii Mari, jud. Dàmboviţa) (Gioglovan 1976, 49-54; Olteanu 2002, 90; Ilie 2005, 64 şi urm.). Acestea din urmă, situate faţă de staţiunea de la Izvoru Burta Vacii, în aceeaşi luncă a Neajlovului, la numai $3,3 \mathrm{~km}$ şi, respectiv, $6,2 \mathrm{~km}$ nord-vest, au beneficiat şi de atenţia echipelor Chronos, ambelor identificându-li-se şanţul de delimitare.

${ }^{20}$ Trohani, Oancea 1976, passin
} 
urilor din văile râurilor interioare din Muntenia, pare să excludă locuiri exterioare de lungă durată, descoperirea celor sezoniere şi/sau temporare necesitând o altă abordare metodologică ${ }^{2 !}$.

Pentru evaluarea nedistructivă a staţiunii de la Vânătorii Mici Momâia au fost utilizate scanarea 3D, fotografiile aeriene oblice, scanarca magnetometrică şi carotajele stratigrafice.

$\mathrm{Nu}$ vom intra aici în detalii tehnice ale fiecărei metode în parte, numeroase elemente regăsindu-se în publicații anterioare ale noastre ${ }^{22}$.

Reamintim, însă, că niciodată o ridicare topografică realizată în parametri clasici nu va acumula sute de mii (uneori milioane) de puncte pentru aceeaşi suprafaţă, aşa cum asigură scanarea 3D (PI. V/2). De aceea, diferenţele dintre expresiile grafice - care, evident, se referă la acurateţe şi precizie - ale ridicărilor topografice ale aceleiaşi suprafețe sunt, uneori, substanţiale, evident, în favoarea celei obţinute prin scanarea 3D. Singura condiţie impusă obiectiv este ca vegetaţia de pe suprafaţa investigată să fie de mici dimensiuni. De aceea, scanarea $3 \mathrm{D}$, şi în acest caz, s-a petrecut, firesc, la începutul primăverii.

Investigația aeriană s-a realizat cu o aeronavă Cessna SkyHawk $172 \mathrm{H}$ şi s-au capturat imagini cu o cameră foto DSRL Canon EOS $400 D$, coordonatele geografice ale siturilor şi traseul de zbor fiind înregistrate cu un GPS Mio 650, soft IGO 2008. Modul de realizare al fotografiilor a fost în plan oblic, prin descrierea unui cerc în jurul sitului, pentru a surprinde, atât structura, peisajul, cât şi punctele de control de la sol care să facă posibilă georeferenţierea fotografiilor.

În cazul acestei stał̧iuni a fost aplicată metoda magnetometriei cu vapori de cesiu, model G858, folosindu-se un gradiometru orizontal, cu cei doi senzori instalați pe un dispozitiv mobil, distanţa dintre linii fiind de un metru. Zona accesibilă din perimetrul tell-ului, delimitată pentru a fi cercetată prin intermediul tehnologiei nedistructive, a însumat o suprafață de aproximativ $2000 \mathrm{~m}^{2}$.

Procesarea datelor a fost făcută într-un proiect GIS și prin intermediul softurilor specifice echipamentului, înlăturându-se, acolo unde a fost posibil, eventualele perturbaţii create de variaţiile diume ale câmpului magnetic total şi zgomotul magnetic de fond.

Atât colţurile suprafeței măsurate magnetometric, cât şi ţintele scanerului $3 \mathrm{D}$ au fost determinate cu ajutorul unui GPS Leica Smart Rover, care a primit corecţii de tip RTK ${ }^{\mathscr{O}}$ Reference, staţie fixă poziţionată pe punctul geodezic având coordonate cunoscute. În acest fel, eroarea maximă a determinării punctelor a fost de $5 \mathrm{~cm}$.

Au fost realizate patru carotaje manuale, amplasate rectiliniu, pe panta estică a tell-ului (Pl. VI/2). Dispunerea lor a avut în vedere atât scanarea magnetometrică, cât şi, mai cu seamă, evitarea zonelor afectate. Şi în acest caz, carotiera - cu un diametru ${ }^{23}$ al sondei de $7,5 \mathrm{~cm}-$ a fost utilizată în paşi altimetrici succesivi de câte $10 \mathrm{~cm}$. Sedimentele recuperate au fost descrise în laborator (anexatabele). Materialele arheologice au fost separate, iar elementele de identificare pentru fiecare în parte fiind apoi prelevate. Adâncimile diferite la care am oprit intervenţiile stratigrafice (PI. V/2) corespund zonelor de niveluri naturale pe care s-a dezvoltat tell-ul sau se datorează lungimii maxime a celor două tijc ale carotierei $(2,60 \mathrm{~m})$.

\section{REZULTATE ŞI DISCUȚII}

Ridicarea topografică realizată prin intermediul scanării 3D (PI. V/1, VI/2), conjugată cu analiza spaţială a hărţilor magnetometrice $(\mathrm{PI}$. VI/2, X/1-4), a relevat faptul că tell -ul are o formă relativ circulară, cu diametrele de $46 \mathrm{~m}$ (aproximativ NE-SV) şi, respectiv, $48 \mathrm{~m}$ (aproximativ NVSE). Forma ovală care este vizibilă pe fotografiile aeriene (PI. IV) nu corespunde realităţii, arăturile de care aminteam mai sus contribuind decisiv la acest aspect. Suprafaţa totală a bazei tell-ului (în fapt, o proiecţie în plan orizontal) include toate elementele de structură identificate.

\footnotetext{
${ }^{21}$ De exemplu, Bailey et alii 1999.

${ }^{22}$ Haită, Bem 2011; Bem et alii 2012; Bem et alii 2013; Bem et alii 2014

${ }^{23}$ Aceastã dimensiune nu are corespondent în scările PI. VII-IX, din motive obiective. Aşa cum scriam şi cu alt prilcj (Bem ef alii 2013,91 ), diametrul mic al intervenţiei stratigrafice realizată prin intermediul carotierei ne determinā sā o considerăm ca având un caracter nedistructiv.
} 
Harta obținută în urma interpolării semnalului magnetic înregistrat afișează o serie de anomalii, în special pozitive (de culoare roșu aprins sau negru), dar și negative (de culoare albastră sau albă) limitate în intervalul $-10-+10 \mathrm{nT}(\mathrm{Pl} . \mathrm{X} / 1-4)$. Forma cvasi-circulară a anomaliei pozitive exterioare, întreruptă în unele locuri, probabil, din cauza lucrărilor agricole întreprinse în această zonă, conduce spre atribuirea acesteia unui șanț de delimitare a tell-ului. Intensitatea semnalului magnetic de aproximativ $20 \mathrm{nT}$, aproape pe tot traseul acesteia, precum și dimensiunile variate (lățimea) care pornesc de la aproximativ $1 \mathrm{~m}$ și pot ajunge până la aproximativ $5 \mathrm{~m}$ sau mai mult (valorile nu pot fi redate în mod precis deoarece este cunoscut faptul că anomaliile magnetice radiază, fiind deseori mai mari decât caracteristicile care au determinat prezența acestora), sunt considerate argumente plauzibile în susținerea ipotezei formulate anterior. Semnalul pozitiv coerent - al şanţului de delimitare, se datorează unei clare intervenţii antropice într-o zonă de sedimente naturale, deranjând-o şi modificându-i substanţial magnetismul.

Anomalia, de asemenea de natură pozitivă, care acoperă centrul hărții noastre vizibil deranjată de unele intervenții recente, dispune de un magnetism mult mai intens (care poate merge, în unele zone, până la aproximativ $40 \mathrm{nT}$ ). Acesta indică prezența unui nivel arheologic consistent, cu numeroase resturi de locuire supuse arderii.

În plus, o anomalie care fluctuează între valorile de -4 şi +4 nT (PI. X, nuanţele de verde/galben sau griul mai închis), al cărei traseu a fost identificat şi în urma analizei aerofotogrametrice (PI. IV/1), reprezintă un curs intermitent de apă sau un fost meandru, astăzi colmatat, al Neajlovului.

Harta magnetometrică a fost întrutotul confirmată de carotajele stratigrafice, în măsura în care acestea din urmă au acoperit acelaşi spaţiu. Din păcate, deşi am încercat evitarea zonelor afectate de diferite intervenţii, carotajul nr. 1 (PI. VII) a fost amplasat într-o zonă care, până la cca. $-1,60 \mathrm{~m}$ (adâncime relativă), era integral distrusă. Sedimentele nu erau în loc, spaţiul respectiv constituind fie una dintre casetele cercetate în 1972-1973, fie rezultatul unei intervenţii neautorizate ulterioare, în ambele cazuri astupate în timp. Cert este faptul că, la suprafaţa solului, acest lucru nu era vizibil. Deşi pe harta magnetometrică (PI. IV/2, X/2-4) era vizibilă o discontinuitate, ea a fost pusă iniţial pe baza unor fluctuaţii magnetice locale. După adâncimea de $1,60 \mathrm{~m}$, sedimentele sunt in situ, coerenţa lor indicând existenţa unor depuneri interpretate ca prezenţă a unor spaţii foste exterioare ale unor locuinţe neincendiate ${ }^{24}$. Acestea suprapun, făă cezură, resturile incendiate ale unei construcţii ${ }^{25}$, dezvoltate stratigrafic pe aproximativ $40 \mathrm{~cm}$ grosime, la partea inferioară individualizându-se o serie de unităţi stratigrafice constructive (podeaua şi refacerile acesteia). $O$ succesiune similară, dar de numai $20 \mathrm{~cm}$ - dimensiuni asemănătoare resturilor de construcţ̧i cercetate în nivelurile inferioare ale tell-urilor de la Bucşani, îi precede stratigrafic (PI. VII). Deşi din motive tehnice - lungimea maximă a tijelor carotierei - nu am putut atinge în acest carotaj fundamentul natural, prezenţa certă a acestuia în carotajul nr. 3 (PI. IX) indică faptul că cele două resturi de construcţii incendiate aparţin primelor momente de locuire a tell-ului.

Acestora le corespunde firesc, în baza carotajului nr. 2 (C2), succesiunea importantă de niveluri ocupaţionale exterioare ${ }^{26}$ cu aparenţă de amenajare intenţionată (PI. VII, IX). Dacă avem în vedere materialele arheologice, inclusiv cele publicate anterior, cât şi situaţiile din amintitele tell-uri de la Bucşani, această secvenţă stratigrafică - cu o grosime care acoperă aproximativ jumătate $(\sim 1,50$ m) din amplitudinea maximă, ar putea aparţine primei faze Gumelniţa. Evident, încadrarea este, totuşi, ipotetică, numai o ccrcetare arheologică propriu-zisă putând oferi certitudini în acest sens.

Urmează, suprapunând această primă secvenţă, un pachet compact şi coerent de unităţi stratigrafice, comparabil cu resturile neincendiate ale unei construcţiii ${ }^{27}$ (PI. VII, IX). Este posibil ca prezenţa unor agregate argiloase foarte compacte (anexa-tabele), care separă în două părţi această coloană, să corespundă unei perioade de abandon. Firesc, atare interpretare implică existenţa a două niveluri de distrugere neincendiate, deci a două construcţii care nu au sfârş̧it prin foc.

\footnotetext{
${ }^{24}$ Bem et alii 2013,93, categoria 4

${ }^{25}$ Bem et alii 2013,93, categoria 5

${ }^{26} \mathrm{Nu}$ au fost incluse în clasificarea noastrā anterioarā (Bem et alii 2013) pentru că, în acel moment, nu fuseseră identificate.

${ }^{27}$ Bem et alii 2013, 93, categoria 3
} 
În sfârşit, succesiunea macrostratigrafică se încheie cu două orizonturi de distrugere ale unor construcţii incendiate (PI. VII; IX, anexa-tabele), conţinând în ambele cazuri, spre partea inferioară, elemente ale unor unităţi constructive şi fiind separate de o unitate stratigrafică care corespunde spaţiului exterior ale unei construcţii distruse în urma unui incendiu ${ }^{28}$. Această secvenţa ar putea aparţine fazei Gumelniţa Bl, confirmări sau infirmări în acest sens putându-se preciza, ca şi în cazul de mai sus, numai în urma unor cercetări arheologice propriu-zise ${ }^{29}$.

Ambele prime carotaje s-au oprit în apropierea fundamentului natural. Acesta a fost interceptat în C3 la o adâncime relativă faţă de partea superioară a C2 de 3,18 m (PI. VIII-IX; anexa-tabele). Pentru că $\mathrm{C} 2$ a fost amplasat în zona de maximã altitudine a tell-ului, chiar dacă se poate presupune că grindul pe care s-a construit tell-ul avea o uşoară pantă, valoarea de 3,20 m indică un maxim al depunerilor antropice.

Pe aproximativ $1 \mathrm{~m}$ grosime, suprapunând grindul amintit, C3 a relevat şi prezenţa unei depuneri de silt argilos, relativ eterogen, cu incluziuni antropice. Corespunzând anomaliei negative din harta magnetometrică (Pl. X/2-4 - albul şi, respectiv, nuanţele de albastru închis), dezvoltată pe o lăţime importantă (între 5 şi $8 \mathrm{~m}$ ), aceasta corespunde unui surplus de material care nu poate fi pus pe seama unor factori naturali, dar nici a acumulării din timpul locuirii tell-ului. Date fiind poziţia stratigrafică şi planimetrică (PI. VI/2, VIII, X/2-4), structura sa intemă, diferenţierea clară fałă de fundamentul natural pe care s-a dezvoltat $t e l l$-ul (anexa-tabele), indiferent de apelativul de identificare - val, dig, obstacol etc., prezenţa acestei macrounităţi în cadrul stratigrafiei tell-ului de la Vânătorii Mici este în afara oricărei îndoieli. De altfel, nu este prima situaţie de acest tip întâlnită în cazul tellurilor mici şi mijlocii din văile râurilor interioare din Muntenia ${ }^{30}$, singura diferenţă fał̧ă de acestea fiind prezenţa unor mai numeroase incluziuni antropice (PI. VIII, anexa-tabele). Aceasta presupune, mai mult decât în celelalte cazuri similare, că valul/digul a fost realizat într-unul din momentele ulterioare debutului locuirii. Evident, această poziţionare în stratigrafia generală a staţiunii nu exclude existența unui obstacol similar care să corespundă primului moment de locuire - dezafectat sau înglobat în cel ulterior.

Structura de delimitare a staţiunii este completată prin şanţul interceptat în C4 (PI. VIII-IX) şi foarte vizibil pe harta magnetometrică (PI. X/1-4 - amintita anomalia pozitivă circulară); aceasta arc în zona carotajului cca $1 \mathrm{~m}$ adâncime şi o lăţime în partea superioară de aproximativ $5 \mathrm{~m}$. Semnalul pozitiv neregulat al şanf̧ului în scanarea magnetometrică - mai cu seamă în zona sudică - poate fi datorat, foarte probabil, nu numai arăturilor din zonă, ci şi chirpiciului ars provenit din intervenţiile stratigrafice contemporane, dislocat şi împrăştiat pe suprafaţa tell-ului.

Din păcate, în acest caz, din cauza datei de survol (iunie) și a condițiilor meteo nefavorabile, analiza fotografiilor aeriene oblice nu a permis identificarea elementului principal de delimitare, rezumându-se doar la precizări de natură peisagistică și geomorfologică.

\section{CONCLUZII}

Valorile dimensionale absolute ale movilei antropice - diametrele de $46 \times 48 \mathrm{~m}$ şi grosimea depunerilor de cca 3,20 m - încadrează tell-ul în zona inferioară a categoriei celor de dimensiuni medii" ${ }^{3 !}$.

În urma scanării magnetometrice, s-a putut preciza existenţa unui şant de delimitare cu un traseu cvasi-circular, săpat la baza movilei, în luncă şi închizând o suprafaţă al cărei diametru mediu este de cca $35 \mathrm{~m}$. De asemenea, zona centrală, efectiv locuită, a tell-ului este marcată magnetometric printr-un semnal coerent pozitiv având o formă grafică general rectangulară (deşi uşor neregulată

\footnotetext{
${ }^{28}$ Bem et alii 2013,93 , categoria 2

${ }^{29}$ Momente de locuire care au sfârşit prin incendii generalizate sunt prezente la partea superioară a stratigrafiilor tuturor tellurilor Gumelniţa cercetate suficient de amplu - în România, Căscioarele Ostrovel (jud. Călăraşi) (Dumitrescu 1965), Teiu (Morintz 1962), Bucşani Pod (Marinescu-Bîlcu et alii 1998; Bem 2002) sau Bucşani Pădure-tell (Bem 2008) şi Bulgaria, Ovčarovo (Todorova et alii 1983) sau Goljamo Delčcvo (Todorova et alii 1975).

${ }^{30}$ Morintz 1962, fig. 1; Bem et alii 2013, 93 şi urm., fig. 10

${ }^{31}$ Bem et alii 2012,25
} 
datorită intervenţiilor stratigrafice contemporane), cu latura de 12-17 m (aşadar, închizând o suprafaţă maximă de cca $210 \mathrm{~m}^{2}-\mathrm{Pl}$. X/4). Nu insistăm aici, rezumându-ne la a aminti o seric de exemple contemporane (la scară crono-culturală) în care această suprafață este delimitată cert de palisade fixate în şanţuri de fundaţie, aşa cum au demonstrat-o săpăturile arheologice la Bucşani $\operatorname{Pod}^{32}$ și Bucşani Pădure-tell ${ }^{33}$ sau Ovčarovo ${ }^{34}$, Goljamo Delčevo ${ }^{35}$ şi Polianiţa $^{36}$ (Pl. X/5).

Pentru că magnetometrul înregistrează semnalul cel mai puternic şi mai apropiat de suprafał̧a solului, devine clar faptul că mărimea spaţiului general-rectangular se referă la ultimul moment de locuire, cum am presupus, Gumelniţa B1, care putea adăposti un număr de 4-5 locuinţe de dimensiuni medii.

Ca şi în alte cazuri, carotajele stratigrafice au confirmat prezenţa şanţului, dar şi a unui obstacol între acesta și suprafaţa propriu-zis locuită (încadrată ferm în amintita suprafałă de cca 210 $\mathrm{m}^{2}$ ) - indiferent cum ar putea fi apelat (dig, val etc.) acesta acoperă o suprafaţă importantă (în general, având 7,5-8 m lăţime), dar având o înălţime relativ mică (sub $1 \mathrm{~m}$ în toate cazurile similare).

Faptul că toate celelalte tell-uri de mici şi medii dimensiuni investigate de către echipele CHRONOS prezintă aceeaşi manieră de construcfie - şanț de delimitare, val/dig (acoperit sau nu în timp), suprafată locuită propriu-zis clar delimitată (PI. X/6), ne determină să afirmăm că acesta este modelul structurii generale interne a tuturora. Acoperirea sau nu a obstacolului depinde în mod direct de dimensiunea pe verticală a tell-ului. Cu cât este mai importantă stratigrafia antropică, cu atât creşte posibilitatea ca depunerile superioare să-l acopere fizic. De exemplu, la Teiü ${ }^{37}$, Bucşani Pod ${ }^{38}$ şi Bucşani Pădure-tell ${ }^{39}$ - tell-uri din partea inferioară a categoriei de dimensiuni medii, toate depunerile antropice contemporane valului se sfârşesc prin simpla adosare la acesta. În cazul Măgurei de la Vătaşi - tell din partea superioară a categoriei de dimensiuni medii, aceleaşi depuneri ating coama valului $^{40}$, pentru ca, în cazul tell-ului de dimensiuni mari de la Schitu Măgura Bobocului, acestea să-I suprapună integral $^{41}$. Fără îndoială, avem în vedere şi momentul de construcţie, dar asupra tuturor acestor aspecte ne vom referi într-o intervenţie ulterioară.

Acest model - construit, evaluat şi aplicat cu succes, va trebui avut în vedere în momentul iniţierii oricărei cercetări arheologice specifice, fie ea preventivă ori sistematică. Lipsa unuia dintre elementele definitorii nu va putea avea decât o singură cauză.

\section{BIBLIOGRAFIE}

Bailey et alii 1999

D. Bailey, R. Andreescu, S. Mills, Southern Romania Archaeological Project. Preliminary report 1998, School of History and Archaeology, Cardiff University, 1999

Bem 2002

C. Bem, Bucşani, com. Bucşani, jud. Giurgiu, Punct: Pod, La Pădure, $C C A, 2002$,

Bem 2007

p. $67-69$

Bem 2008

C. Bem (ed.), Repertoriul Microzonei Bucşani, Bucureşti, 2007

Bem 2011a C. Bem, Le corpus des stations Gumelniţa entre Danube et Mer Noire (avec un

C. Bem, Bucşani, com. Bucşani, jud. Giurgiu, Punct: La Pod, Pădure, CCA, 2008, http://cimec.ro/Arheologie/cronicaCA2008/cd/index.htm regard sur Boian-Spanţov et Cemavoda I), în L. Carozza, C. Bem, C. Micu (eds.),

\footnotetext{
${ }^{32}$ Bem et alii 2010a; Bem $2011 \mathrm{c}$

${ }^{33}$ Bem 2012

${ }^{34}$ Todorova et alii 1983

${ }^{35}$ Todorova et alii 1975

${ }^{36}$ Todorova 1982

${ }^{37}$ Morintz 1962

${ }^{38}$ Bem $201 \mathrm{lc}$

${ }^{39}$ Bem 2012

${ }^{40}$ Bem et alii 2013,95 , fig. 10

${ }^{4 i}$ Bem et alii 2014
} 
Bem $2011 b$

Bem 201 lc

Bem 2012

Bem et alii 2010a

Bem et alii $2010 \mathrm{~b}$

Bem et alii 2012

Bem et alii 2013

Bem et alii 2014

Dumitrescu 1965

Gioglovan 1976

Haită, Bem 2011

Ilie 2005

Marinescu-Bîlcu

et alii 1998

Morintz 1962

Olteanu 2002

Todorova 1982

Todorova et alii 1975

Todorova et alii 1983

Trohani, Oancea 1976
Société et environnement dans la zone du Bas Danube durant le 5ème millénaire avant notre ère, Iaşi, 2011 , p. 3-77

C. Bem, Vision d'ensemble de l'occupation Gumelniţa en Dobroudja, in L. Carozza, C. Bem, C. Micu (eds.), Société et environnement dans la zone du Bas Danube durant le Sème millénaire avant notre ère, 2011, p. 131-197

C. Bem, Bucşani, com. Bucşani, jud. Giurgiu, Punct: Pod, CCA, 2011, http://cimec.ro/Arheologie/cronicaCA2011/cd/index.htm

C. Bem, Bucşani, com. Bucşani, jud. Giurgiu, Punct: Pod, Pădure - Şcoală și Tell, $C C A, 2012$, http://cimec.ro/arheologie/cronicaCA2012/cd/index.htm

C. Bem, V. Cotiugă, A. Asăndulesei, B. Venedict, C. Nicu, R. Balaur, Magnetometric prospection in archaeological sites of Gumelniţa culture, National Symposium of Archaeometry, Bucharest, Romania, 25-29 octombrie 2010

C. Bem, V. Cotiugă, A. Asăndulesei, B. Venedict, C. Nicu, R. Balaur, Un posibil model de <construcţie > a tell-urilor de dimensiuni mici, Simpozionul Tell-uri la Dunărea de Jos, Giurgiu, 25 noiembrie 2010

C. Bem, A. Asăndulesei, Carmen Bem, F.-A. Tencariu, V. Cotiugă, Şt. Caliniuc, Identity in diversity: photogrammetry, 3d laser scanning and magnetometric analysis of Gumelniţa tells from Muntenia (Romania), în V. Cotiugă, Șt. Caliniuc (eds.) Interdisciplinarity Research in Archaeology. Proceedings of the First Arheoinvest Congress, 10-11 June 2011, Iaşi, Romania, BAR International Series 2433, 2012, p. 19-36

C. Bem, A. Asăndulesei, C. Haită, Carmen Bem, M. Florea, Interdisciplinary investigations. The tell settlement from Vătaşi Măgura (Teleorman county, Romania), Studii de Preistorie 10, 2013, București, p. 89-117

C. Bem, C. Haită, A. Asăndulesei, Carmen Bem, V. Opriş, Tell-urile gumelniţene gigant din bazinul inferior al Câlniștei (Muntenia, România), conferință care va fi susținută la Simpozionul anual Aşezări şi teritoriile lor. Abordări metodologice şi studii de caz, Valea Alunului, Hunedoara, 8-11 mai 2014

Vl. Dumitrescu, Principalele rezultate ale primelor două campanii de săpătură din aşezarea neolitică târzie de la Căscioarele, $S C I V, 16,1965,2$, p. 215-237

R. Gioglovan, Raport preliminar de cercetare arheologică la Moara din Groapă, jud. Dâmboviţa (1976). Intervenţie de salvare, Archiva Valachica, 8, Târgoviște, 1976, p. 49-54

C. Haită, C. Bem Données stratigraphiques des sites pluristratifiés, în L. Carozza, C. Bem, C. Micu (eds.), Société et environnement dans la zone du Bas Danube durant le Sème millénaire avant notre ère, lași, 2011, p. 89-99

Ana Ilie, Contribuţii la repertoriul arheologic al judeţului Dâmboviţa. Situri preistorice pe Valea Neajlovului, Valachica, 18, 2005, p. 61-71, 331-334

Silvia Marinescu-Bîlcu, R. Andreescu, C. Bem, T. Popa, M. Tănase, Santierul arheologic Bucşani (jud. Giurgiu). Raport preliminar. Campania 1998, în Buletinul Muzeului Judejean ,, Teohari Antonescu”, Giurgiu, 2-4, 1998, p. 93-114

S. Morintz, Tipuri de aşezări şi sisteme de fortificaţie şi de împrejmuire în cultura Gumelniţa, SCIV, 13, 1962, 2, p. 273-284

Gh. Olteanu, Repertoriul arheologic al judetului Dâmbovita. Volumul I $(A-M)$, Târgovişte, 2002

Henrieta Todorova, Kupferzeitliche Siedlungen in Nordostbulgarien, Materialien zur Allgemeinen und Vergleichenden Archäologie 13, Verlag C.H. Beck, München, 1982

Henrieta Todorova, St. Ivanov, V. Vasilev, M. Hopf, H. Quitta, G. Kohl, Голямо Делчево, Разкопки и Проучвания 5, Известия на Българския Археологически институт, София, 1975.

Henrieta Todorova, V. Vasilev, Z. Ianucevici, M. Kovaceva, P. Vîlev, Овчарово, Разкопки и Проучвания 8, Известия на Българския Археологически институт, София, 1983

G. Trohani, Al. Oancea, Descoperiri arheologice pe teritoriul comunei Vînătorii Mici, judeţul Ilfov, $C A, 4,1976$, p. 19-32 
PI. I. 1. The location of the Vânătorii Mici area in the general regional assembly; 2. The location of the Vânătorii Mici Momaia tell in the zonal framework

PI. II. 1. The zone of interest on the Szathmári map (1864); 2. The visibility areas of the two tells from the zone of Vânătorii Mici village; 3. The fountain of the mansion Crețeanu from Izvoru (rebuilt in 1911); 4. Izvoru Burta Vacii. View from the NW side of the tell. 5. Vânătorii Mici Momâia. View from the SE side of the tell

PI. III. 1-5. Ceramic objects and vessels discovered in the tell from Vânătorii Mici (after Trohani, Oancea 1976)

Pl. IV. Vânătorii Mici Momâia. 1. Aerial photography, non-georeferenced (from the W) - red arrows mark intermittent water courses (the most important is probably a former meander of Neajlov); the circle includes the tell and the black arrow marks the section of research in 1972-1973; 2 . Aerial photography, non-georeferenced (from the E). In the background runs the Neajlov terrace

PI. V. 1. Topographic survey of the tell from Vânătorii Mici Momâia and the surrounding area (3D laser scanning - Bogdan Venedict; the two perpendicular lines mark two of the boundaries of the magnetometric investigated area; scale is based on the axes of Stereo70 coordinates); 2. Vânătorii Mici Momâia. Relative locations of stratigraphic corings. $1 . Z_{0}$ is the reference point of the station; $2 . Z_{0}$ is represented by coring $C 2$

PI. VI. 1. Vânătorii Mici Momâia. 1. The magnetometric scanned surface; 2. The location of corings

Pl. VII. Vânătorii Mici Momâia. The internal stratigraphy of corings $n^{\circ} 1$ and $n^{\circ} 2$

Pl. VIII. Vânătorii Mici Momâia. The internal stratigraphy of corings $n^{\circ} 3$ and $n^{\circ} 4$

PI. IX. Vânătorii Mici Momâia. The stratigraphic sketch of the tell revealed by the four corings

PI. X. 1-4. Vânătorii Mici Momâia. The magnetometric map; 5. The plan of the settlement from Polianif̧a (after Todorova 1982); 6. Idealized sketch of the begining moment of each independent occupation in a tell

CĂTĂLIN BEM, VASILE OPRIŞ Muzeul Naţional de Istorie a României, Secției de Arheologie Pre- și Protoistorică, Clasică și Medievală catalinbem@yahoo.com; vasilelieopris@yahoo.com CONSTANTIN HAITÃ

Centrul Naţional de Cercetări Pluridisciplinare „Alexandra Bolomey” costel_haita@yahoo.com

CARMEN BEM

Compania Naţională de Autostrăzi şi Drumuri Naţionale din România, carmen.bem@andnet.ro ANDREI ASĀNDULESEI

Universitatea „Alexandru Ioan Cuza” Iaşi andrei.asandulesei@yahoo.com 
Anexă-tabele. Descrierea succesiunilor stratigrafice ale carotajelor $1-4$

Carotajul nr. I (PI. VII, IX)

\begin{tabular}{|c|c|c|}
\hline $\begin{array}{c}\text { Adâncime } \\
(\mathrm{cm})\end{array}$ & Descriere şi incluziuni antropice & Interpretare \\
\hline $0-40$ & $\begin{array}{l}\text { Silt argilos, brun mediu şi brun deschis, cu structură agregată, omogen, cu } \\
\text { rădăcini actuale. Conţine rare granule mm şi câteva de } 1-2 \mathrm{~cm} \text { rulate, de } \\
\text { chirpici ars }\end{array}$ & \multirow{5}{*}{$\begin{array}{l}\text { Intervenţie } \\
\text { contemporană }\end{array}$} \\
\hline $40-60$ & $\begin{array}{l}\text { Silt argilos, brun deschis, omogen, relativ steril. Conţine foarte rare granule } \\
\text { mm de chirpici ars, } 1 \text { fragment de scoică } 3 \mathrm{~mm}\end{array}$ & \\
\hline $60-80$ & $\begin{array}{l}\text { Silt argilos, brun deschis, mai eterogen. Conţine rare granule de chirpici }<1 \\
\mathrm{~cm} \text { rulate, } 1 \text { fragment de chirpici scorificat de cca. } 3 \mathrm{~cm}, 1 \text { fragment de rocă } \\
0,5 \mathrm{~cm} \text { şi câteva granule fine de cărbune }\end{array}$ & \\
\hline $80-90$ & $\begin{array}{l}\text { Silt argilos, brun gălbui, eterogen, cu frecvente granule fine }(\mathrm{mm}) \text { de } \\
\text { chirpici ars }(10-15 \%) \text { la roşu și rare granule } \sim 1 \mathrm{~cm}\end{array}$ & \\
\hline $90-160$ & $\begin{array}{l}\text { Silt argilos, brun gălbui, eterogen, cu granule fine de chirpici ars (cca. } 5 \% \text { ), } \\
\text { rare granule }<1 \mathrm{~cm} \text {, rulate, câteva granule de } 1-2 \mathrm{~cm} \text { și câteva granule de } 1 \\
\text { cm de cărbune. Chirpiciul este amestecat cu matricea sedimentară }\end{array}$ & \\
\hline $160-180$ & $\begin{array}{l}\text { Silt argilos, brun gălbui, omogen, cu foarte rare granule de chirpici ars mm } \\
\text { ș câteva granule de } 1-2 \mathrm{~cm} \text { mai compacte, rulate }\end{array}$ & Nivel de locuire. \\
\hline $180-200$ & $\begin{array}{l}\text { Silt argilos, brun gălbui, omogen. Conţine granule de chirpici ars fin (2- } \\
5 \% \text { ), câteva fragmente de chirpici compact, } 1-3 \mathrm{~cm}, 1 \text { fragment de rocă } 1 \\
\mathrm{~cm}, 1 \text { fragment de scoică } 1 \mathrm{~cm} \text {. }\end{array}$ & Nivel de locuire \\
\hline $200-210$ & $\begin{array}{l}\text { Silt argilos cu nisip mediu, brun gălbui şi gãlbui, eterogen, ce conţine cca. } \\
30 \% \text { chirpici ars la roșu şi gălbui }\end{array}$ & $\begin{array}{l}\text { Distrugere } \\
\text { incendiată }\end{array}$ \\
\hline $210-220$ & $\begin{array}{l}\text { Nivel de chirpici brun cărămiziu mediu, omogen, ce conţine cca. } 80 \% \\
\text { chirpici ars fin şi cca. } 10 \% \text { fragmente de chirpici compact de } 1-3 \mathrm{~cm}, 1 \text { galet } \\
\text { de cuarţit de } 1,5 \mathrm{~cm} \text { și rare granule de cărbune fin }\end{array}$ & $\begin{array}{l}\text { Distrugere } \\
\text { incendiată }\end{array}$ \\
\hline $220-230$ & $\begin{array}{l}\text { Silt argilos, brun cenuşiu mediu, omogen, ce conţine cca. } 10-15 \% \text { granule } \\
\text { fine de chirpici şi cca. } 10 \% \text { granule carbonatice mm, rare granule de cărbune } \\
\text { fin, un fragment de cărbune de } 1,5 \mathrm{~cm}\end{array}$ & $\begin{array}{l}\text { Distrugere } \\
\text { incendiată }\end{array}$ \\
\hline $230-240$ & $\begin{array}{l}\text { Silt argilos, brun cenuşiu închis, omogen, ars, ce conţine cca. } 5 \% \text { granule } \\
\text { carbonatice, rare fragmente fine de cărbune, unul de } 1 \mathrm{~cm}\end{array}$ & $\begin{array}{l}\text { Distrugere } \\
\text { incendiată. } \\
\text { Niveluri de podea }\end{array}$ \\
\hline $240-250$ & $\begin{array}{l}\text { Nivel de chirpici ars, brun cărămiziu mediu, omogen, compact, cu granule } \\
\text { mm de chirpici compact, mai rar } 1-2 \mathrm{~cm} \text {, cca. } 90 \%, 2 \text { fragmente ceramice } \\
\text { arse secundar }\end{array}$ & $\begin{array}{l}\text { Distrugere } \\
\text { incendiată. }\end{array}$ \\
\hline $250-260$ & $\begin{array}{l}\text { Silt argilos, brun cenuşiu mediu, cu frecvente granule de argilă cenuşiu } \\
\text { mediu, foarte omogenă, cu rare granule de chirpici ars compact de } \sim 1 \mathrm{~cm}, 1 \\
\text { fragment ceramic ars secundar }\end{array}$ & $\begin{array}{l}\text { Distrugere } \\
\text { incendiată. } \\
\text { Niveluri de podea }\end{array}$ \\
\hline
\end{tabular}

Carotajul nr. 2 (PI. VII; IX)

\begin{tabular}{|l|l|l|}
\hline $\begin{array}{c}\text { Adâncime } \\
\text { (cm) }\end{array}$ & \multicolumn{1}{|c|}{ Descriere şi incluziuni antropice } & \multicolumn{1}{|c|}{ Interpretare } \\
\hline $0-15$ & $\begin{array}{l}\text { Silt argilos, brun mediu, relativ omogen, cu structură agregată şi frecvente } \\
\text { rădăcini actuale. Conţine cca. 30\% granule de chirpici ars 1-3 cm }\end{array}$ & $\begin{array}{l}\text { Sol actual. } \\
\text { Nivel de distrugere }\end{array}$ \\
\hline $15-40$ & $\begin{array}{l}\text { Silt argilos cu nisip mediu-grosier, brun cărămiziu deschis şi brun } \\
\text { deschis, eterogen, compact, ce conţine } 90 \% \text { fraginente de chirpici ars, } \\
\text { mai rar şi mai fin spre partea inferioară, şi rare granule de cărbune fin }\end{array}$ & $\begin{array}{l}\text { Nivel de distrugere } \\
\text { incendiat. } \\
\text { Podele incendiate }\end{array}$ \\
\hline $40-50$ & $\begin{array}{l}\text { Silt argilos cu nisip mediu, brun deschis, aspect eterogen, conţine cca. } \\
5 \% \text { chirpici ars şi cărbune fin, câteva fragmente de } 1 \mathrm{~cm} .\end{array}$ & Nivel de locuire \\
\hline
\end{tabular}




\begin{tabular}{|c|c|c|}
\hline $50-70$ & $\begin{array}{l}\text { Nivel de chirpici ars, brun cărămiziu deschis şi brun roşcat, eterogen, } \\
\text { conține } 70-90 \% \text { fragmente de chirpici ars de } 2-3 \mathrm{~cm} \text { şi cărbune } 1-2 \mathrm{~cm} \text {, } \\
\text { mai rar cărbune fin }\end{array}$ & $\begin{array}{l}\text { Nivel de distrugere } \\
\text { incendiat }\end{array}$ \\
\hline $70-90$ & $\begin{array}{l}\text { Silt argilos, brun cenuşiu mediu şi brun cărămiziu, relativ omogen, ce } \\
\text { conține } 80-100 \% \text { granule de chirpici friabil și granule de argilă }\end{array}$ & Podele incendiate \\
\hline $90-160$ & $\begin{array}{l}\text { Argilă siltică, brun cenuşiu deschis şi brun gălbui, foarte omogenă, cu } \\
\text { rare incluziuni: } 6 \text { fragmente ceramice, } 2 \text { galeţi de cuarţit } 1-1,5 \mathrm{~cm}, 1 \\
\text { granul de chirpici ars de } 1 \mathrm{~cm} \text {, câteva granule mm de cărbune. Include un } \\
\text { nivel }(\mathbf{1 3 0 - 1 4 0} \mathrm{cm}) \text { cu cca. } 15 \% \text { agregate argiloase foarte compacte }\end{array}$ & $\begin{array}{l}\text { Distrugere } \\
\text { neincendiată. } \\
\text { Podele neincendiate }\end{array}$ \\
\hline $160-250$ & $\begin{array}{l}\text { Silt argilos cu nisip fin-mediu, brun cenuşiu mediu, omogen, cu rari } \\
\text { constituenți antropici şi rare concreţiuni carbonatice de } 1-3 \mathrm{~cm} \text {. Include } \\
\text { câteva granule de chirpici ars } \sim 1 \mathrm{~cm}, 6 \text { fragmente ceramice de } 1,5-2 \mathrm{~cm} \text {, } \\
3 \text { fragmente de rocă de } 1-2 \mathrm{~cm}, 2 \text { valve întregi de } 2,5-3 \mathrm{~cm} \text { şi rare } \\
\text { granule de cărbune fin }\end{array}$ & $\begin{array}{l}\text { Niveluri } \\
\text { ocupaţionale. } \\
\text { Zonă exterioară } \\
\text { amenajată }\end{array}$ \\
\hline $250-260$ & $\begin{array}{l}\text { Silt argilos cu nisip mediu, brun cenuşiu deschis şi gălbui, relativ } \\
\text { eterogen, cu rare granule fine de chirpici ars, } 5 \text { fragmente ceramice, } 1 \\
\text { fragment de rocă de } 1 \mathrm{~cm} \text { şi } 2 \text { fragmente de scoică de } 1-1,5 \mathrm{~cm}\end{array}$ & Nivel de locuire \\
\hline
\end{tabular}

Carotajul nr. 3 (Pl. VII; IX)

\begin{tabular}{|c|c|c|}
\hline $\begin{array}{l}\text { Adâncime } \\
\text { (cm) }\end{array}$ & Descriere şi incluziuni antropice & Interpretare \\
\hline $0-30$ & $\begin{array}{l}\text { Silt argilos, brun mediu şi brun deschis, omogen, cu structură agregată, } \\
\text { cu rădăcini actuale. Include foarte rare granule mm de chirpici ars şi } \\
\text { cărbune, rare fragmente de chirpici ars de } 1-2 \mathrm{~cm}, 1 \text { fragment ceramic, } 1 \\
\text { fragment de rocă de } 1,5 \mathrm{~cm}, 1 \text { scoică de } 2 \mathrm{~cm}\end{array}$ & Sol actual, coluviu \\
\hline $30-50$ & $\begin{array}{l}\text { Silt argilos, brun deschis, relativ omogen, ce conţine rare granule mm de } \\
\text { chirpici ars, } 2 \text { fragmente de chirpici și } 2 \text { fragmente ceramice, } 5 \text { granule } \\
\text { carbonatice de } \sim 1 \mathrm{~cm}\end{array}$ & Coluviu \\
\hline $50-90$ & $\begin{array}{l}\text { Silt argilos, brun gălbui, relativ eterogen, cu foarte rare rădăcini actuale. } \\
\text { Conţine rare concreţiuni carbonatice de } 0,5-1,7 \mathrm{~cm}, 2 \text { granule de chirpici } \\
\text { ars de } 1 \mathrm{~cm} \text { şi rare granule mm, } 11 \text { fragmente ceramice de } 1-2,5 \mathrm{~cm}, 2 \\
\text { cochilii de } 2,5 \mathrm{~cm} \text { (una întreagă) şi } 9 \text { fragmente de cochilii de } 1-2 \mathrm{~cm}, 1 \\
\text { fragment de os de } 1 \mathrm{~cm}\end{array}$ & Amenajare \\
\hline $90-120$ & $\begin{array}{l}\text { Silt argilos, brun cenuşiu deschis, relativ eterogen. Include rare } \\
\text { concreţiuni carbonatice } 0,5-1,5 \mathrm{~cm}, 6 \text { fragmente de chippici ars de } 1 \mathrm{~cm} \text {, } \\
10 \text { fragmente ceramice, } 1 \text { galet de cuarţit de } 1 \mathrm{~cm}, 3 \text { fragmente de } \\
\text { cochilie de scoică de } 1-3 \mathrm{~cm}\end{array}$ & Amenajare \\
\hline $120-150$ & $\begin{array}{l}\text { Silt argilos, brun cenuşiu deschis, relativ eterogen. Include granule } \\
\text { argiloase gălbui de } 1-2 \mathrm{~cm}(5 \%) \text {. Conține rare granule fine de chirpici } \\
\text { ars, } 2-3 \% \text { cărbune mm şi câteva fragmente de } 1 \mathrm{~cm}, 6 \text { fragmente } \\
\text { ceramice, } 1 \text { fragment de rocă de } 2,5 \mathrm{~cm} \text { şi } 3 \text { galeţi de cuarțit de } 0,5-2 \mathrm{~cm} \text {. }\end{array}$ & Amenajare \\
\hline $150-170$ & $\begin{array}{l}\text { Argilă siltică cu nisip fin-grosier, brun gălbui, foarte eterogenă, slab } \\
\text { sortată, cu rare elemente de pietriş fin, cuarţitice, de } 1-2 \mathrm{~cm} \text {, steril }\end{array}$ & Acumulare naturală \\
\hline $170-180$ & $\begin{array}{l}\text { Argilă siltică cu nisip fin-grosier şi rar pietris fin, brun gălbui, foarte } \\
\text { eterogenă, slab sortată, cu rare concreţiuni feruginoase }\end{array}$ & Acumulare naturală \\
\hline
\end{tabular}




\begin{tabular}{|c|c|c|}
\hline $\begin{array}{l}\text { Adâncime } \\
\text { (cm) }\end{array}$ & Descriere şi incluziuni antropice & Interpretare \\
\hline $0-30$ & $\begin{array}{l}\text { Silt argilos, brun mediu și brun deschis, omogen, cu structură agregată și } \\
\text { rădăcini actuale. Include rare granule mm de chirpici ars, } 2 \text { fragmente } \\
\text { ceramice } 1,5-2 \mathrm{~cm}, 1 \text { galet de cuarţit de } 1 \mathrm{~cm}\end{array}$ & Sol actual, coluviu \\
\hline $30-90$ & $\begin{array}{l}\text { Silt argilos cu nisip fin-mediu, brun deschis, omogen, cu foarte rare } \\
\text { granule mm de chirpici ars, câteva granule de } 1 \mathrm{~cm} \text {, rulate şi } 1 \text { fragment } \\
\text { ceramic de } 1 \mathrm{~cm} \text {, rulat }\end{array}$ & Coluviu \\
\hline $90-100$ & $\begin{array}{l}\text { Argilă şi nisip fin, brun cenuşiu gălbui, foarte omogenă, cu rare granule } \\
\text { de chirpici ,descompuse", } 3 \text { fragmente ceramice }\end{array}$ & Umplutură \\
\hline $100-110$ & $\begin{array}{l}\text { Argilă cu nisip fin, brun gălbui, eterogenă, cu 3-5\% chirpici ars } \sim 1 \mathrm{~cm} \\
\text { degradat }\end{array}$ & Umplutură. \\
\hline $110-150$ & $\begin{array}{l}\text { Argilă cu nisip mediu-grosier, brun gălbui, eterogenă, cu 1-2\% granule } \\
\text { de chirpici ars şi } 4 \text { ceramice degradate } \sim 1 \mathrm{~cm} \text { şi câteva fragmente de } \\
\text { chirpici ars compact, rulat, de } 1 \mathrm{~cm}\end{array}$ & Umplutură \\
\hline $150-160$ & $\begin{array}{l}\text { Argilă cu nisip grosier mai frecvent, brun gălbui, eterogenă, cu } 2-3 \% \\
\text { granule de chirpici ars şi concrețiuni grezoase, brun deschis, degradate, } 4 \\
\text { fragmente ceramice şi } 2 \text { granule de cuarţit de } 1-4 \mathrm{~cm}\end{array}$ & Umplutură \\
\hline $160-170$ & $\begin{array}{l}\text { Argilă cu rar nisip grosier și pietriş fin, brun gălbui, eterogenă, cu } 5 \% \\
\text { fragmente ceramice și rare granule de chirpici ars }<1 \mathrm{~cm} \text { degradate, } \\
\text { câteva granule cm, rulate, și rare granule mm de chirpici ars. }\end{array}$ & Umplutură. \\
\hline $170-190$ & $\begin{array}{l}\text { Argilă siltică cu pietriş fin, brun cenuşiu deschis, relativ omogenă, cu } \\
\text { rare }(<1 \%) \text { granule de chirpici ars mm, } 4 \text { fragmente ceramic de } 1,5 \mathrm{~cm} \text {, } \\
\text { rulat, şi } 2 \text { galeţi de cuarţit de } 2-3 \mathrm{~cm}\end{array}$ & Umplutură \\
\hline $190-220$ & $\begin{array}{l}\text { Nisip grosier și pietriş fin-mediu, } 0,5-4 \mathrm{~cm} \text {, gălbui, omogen, slab sortat, } \\
\text { steril }\end{array}$ & Acumulare naturală \\
\hline
\end{tabular}




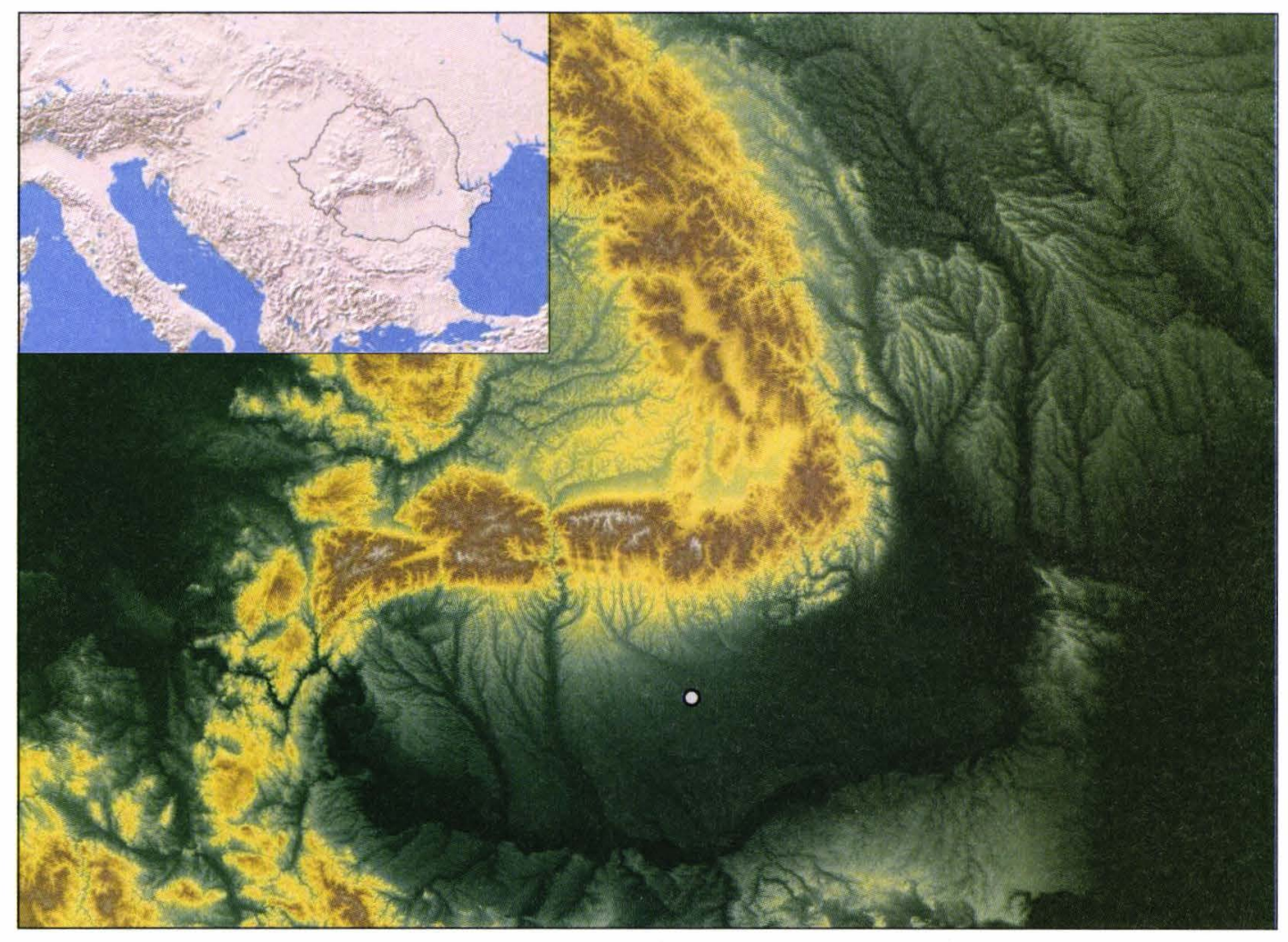

1.

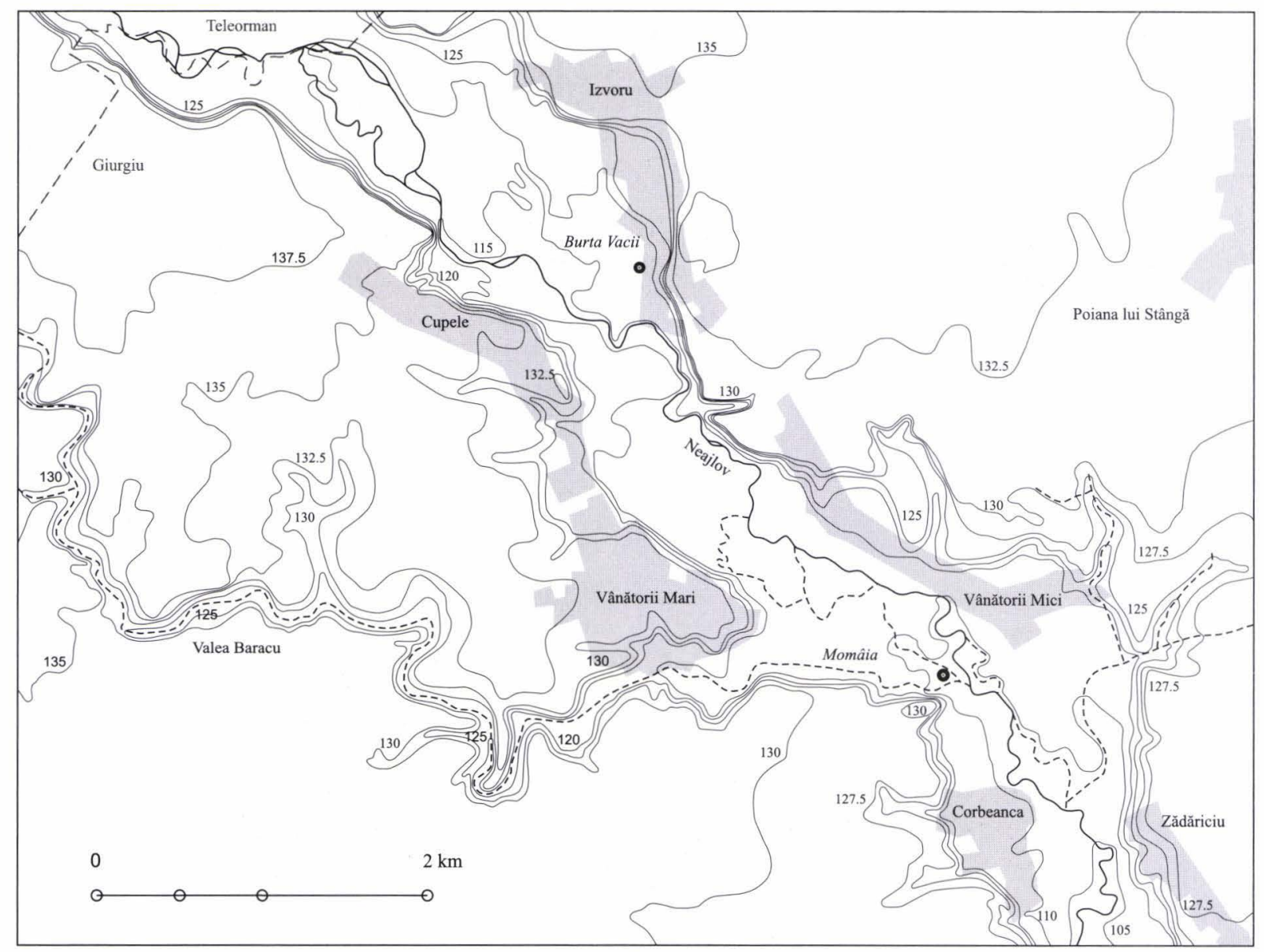

2.

1. Amplasamentul zonei Vânătorii Mici în ansamblul general regional. 2. Amplasamentul tell-ului de la Vânătorii Mici Momâia în cadrul zonal 


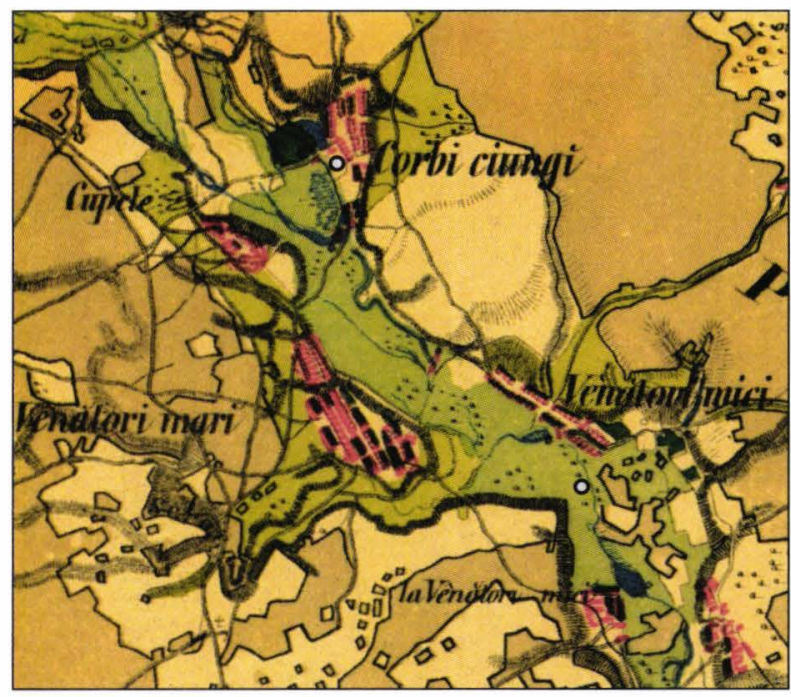

1.

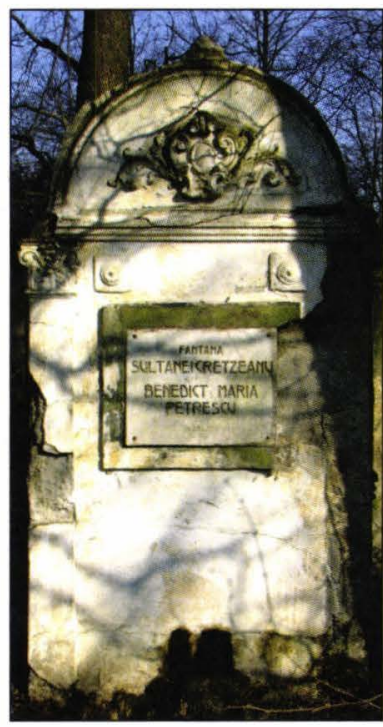

3.

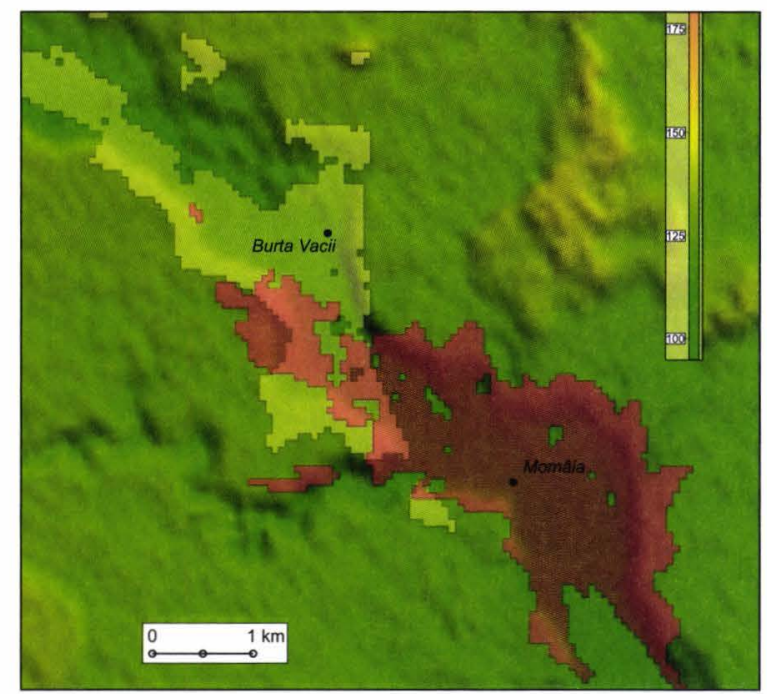

2.

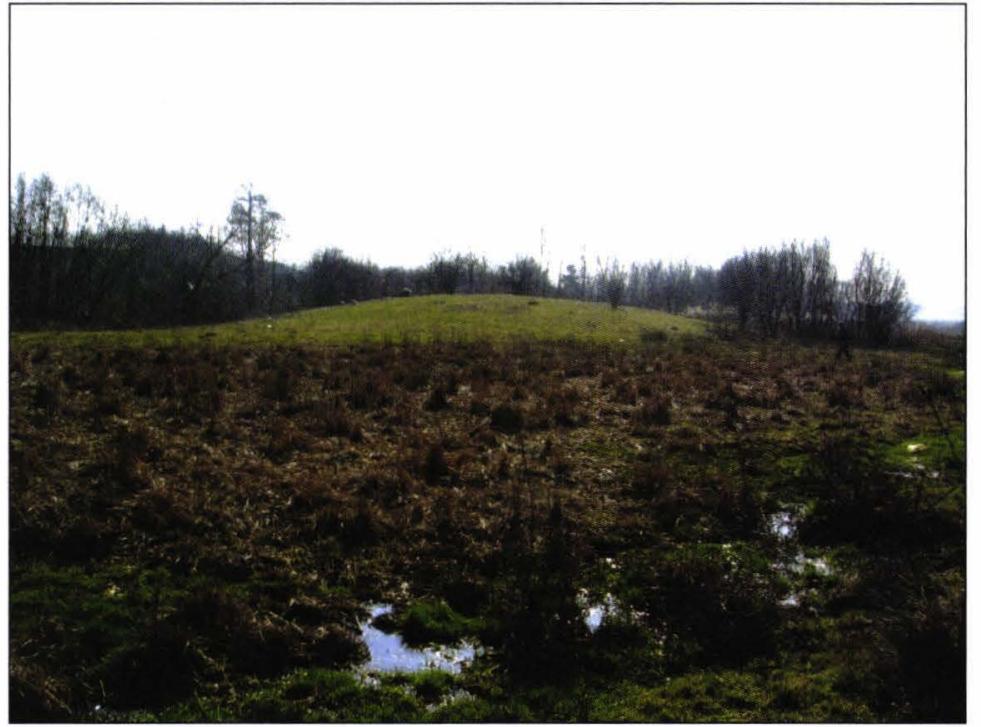

4.

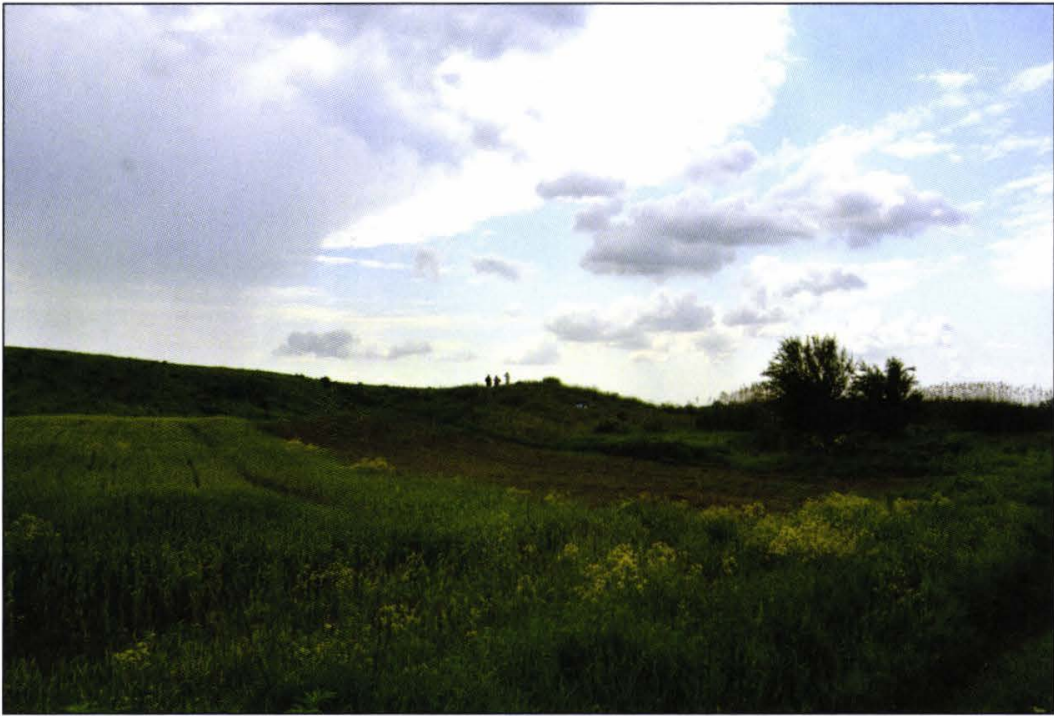

5.

1. Zona de interes pe Harta Szathmári (1864); 2. Ariile de vizibilitate ale celor două tell-uri din zona comunei Vânătorii Mici; 3. Fântâna conacului Creţeanu din Izvoru (refăcută în anul 1911); 4. Izvorul Burta Vacii. Imagine dinspre NV; 5. Vânătorii Mici Momâia. Vedere dinspre SE 


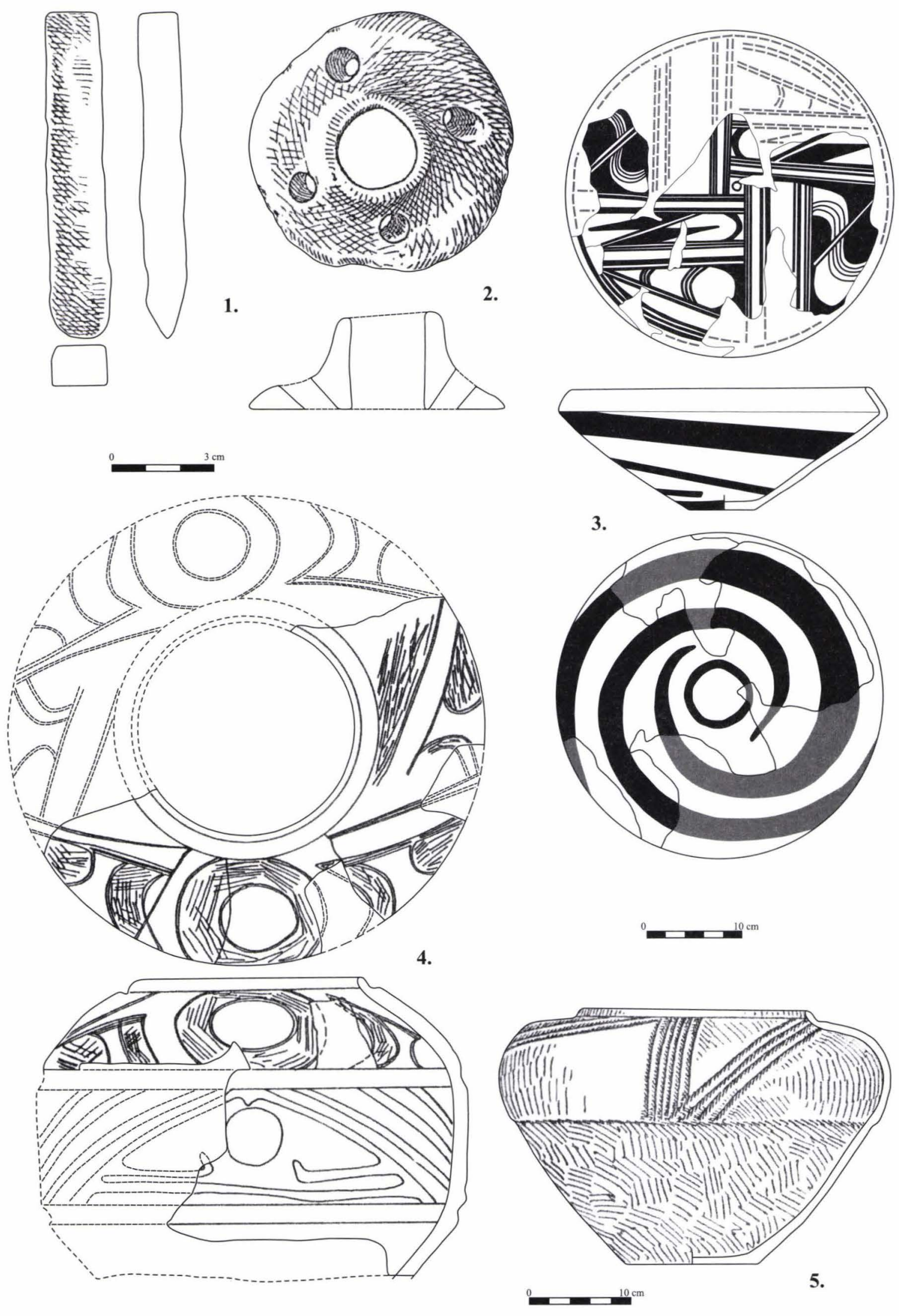

1-5. Piese şi vase ceramice descoperite în tell-ul de la Vânătorii Mici (apud Trohani, Oancea 1976) 


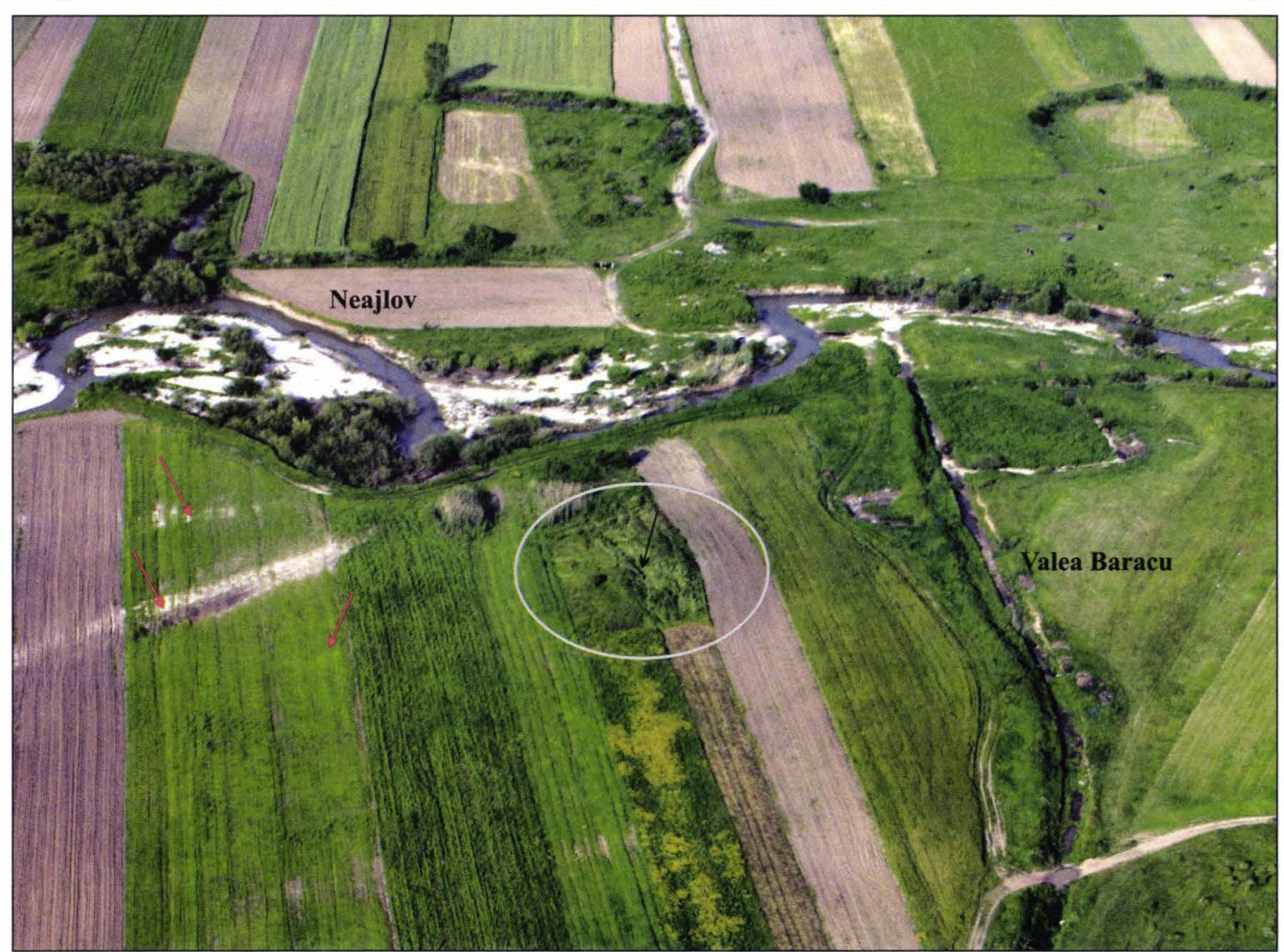

1.



2.

Vânătorii Mici Momâia: 1. Fotografie aeriană negeoreferențiată (dinspre V) - săgețile roșii marchează cursurile intermitente de apă (cel mai important este, foarte probabil, un fost meandru al Neajlovului; cel din plan apropiat mai vizibil, a fost identificat și în scanarea magnetomertrică); ovalul include tell-ul, iar săgeata neagră marchează secțiunea de cercetare dintre anii 1972-1973. 2. Fotografie aeriană negeoreferenţiată (dinspre E); în plan secund se desfăşoară terasa dreaptă a Neajlovului 


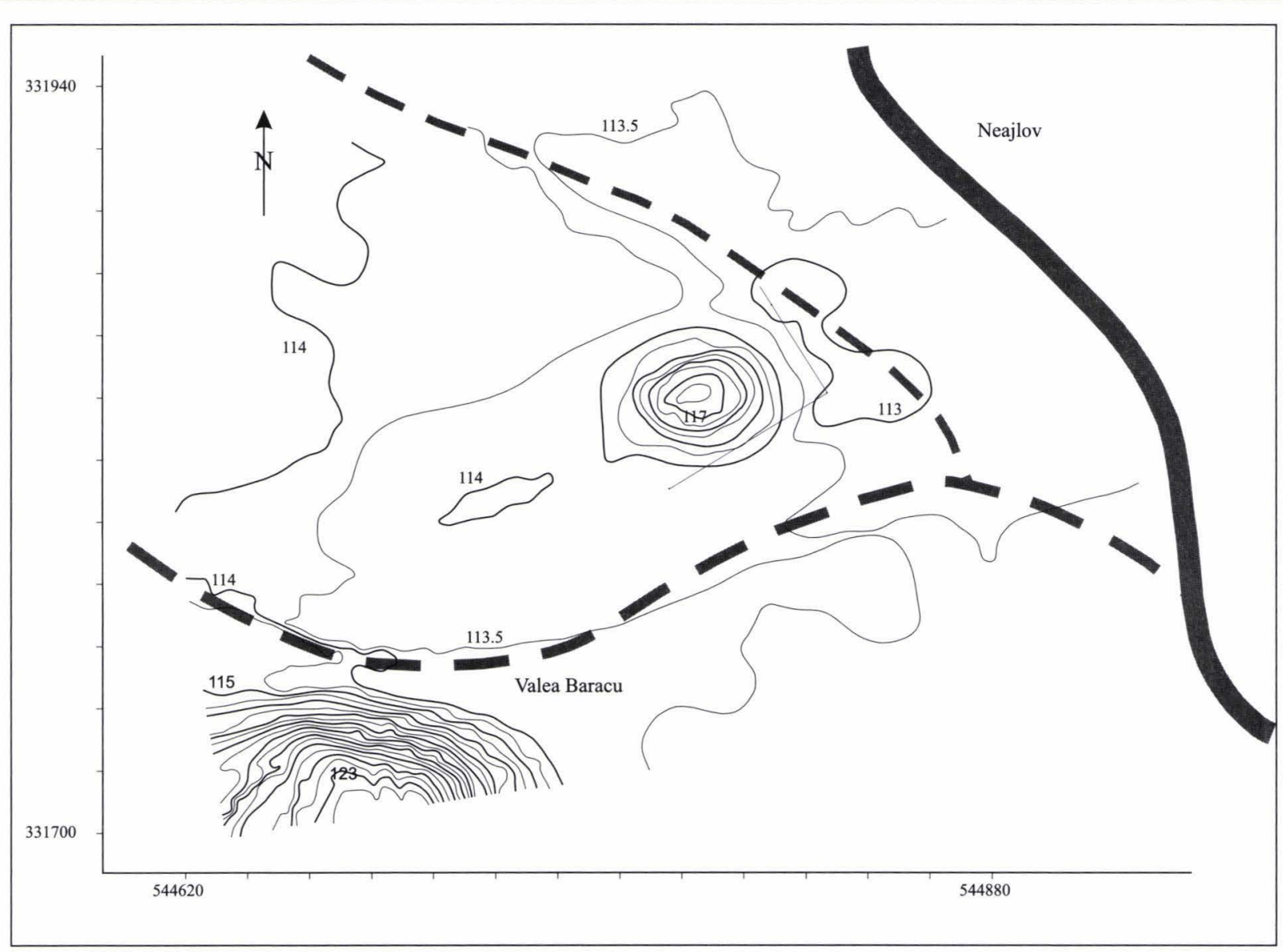

1.

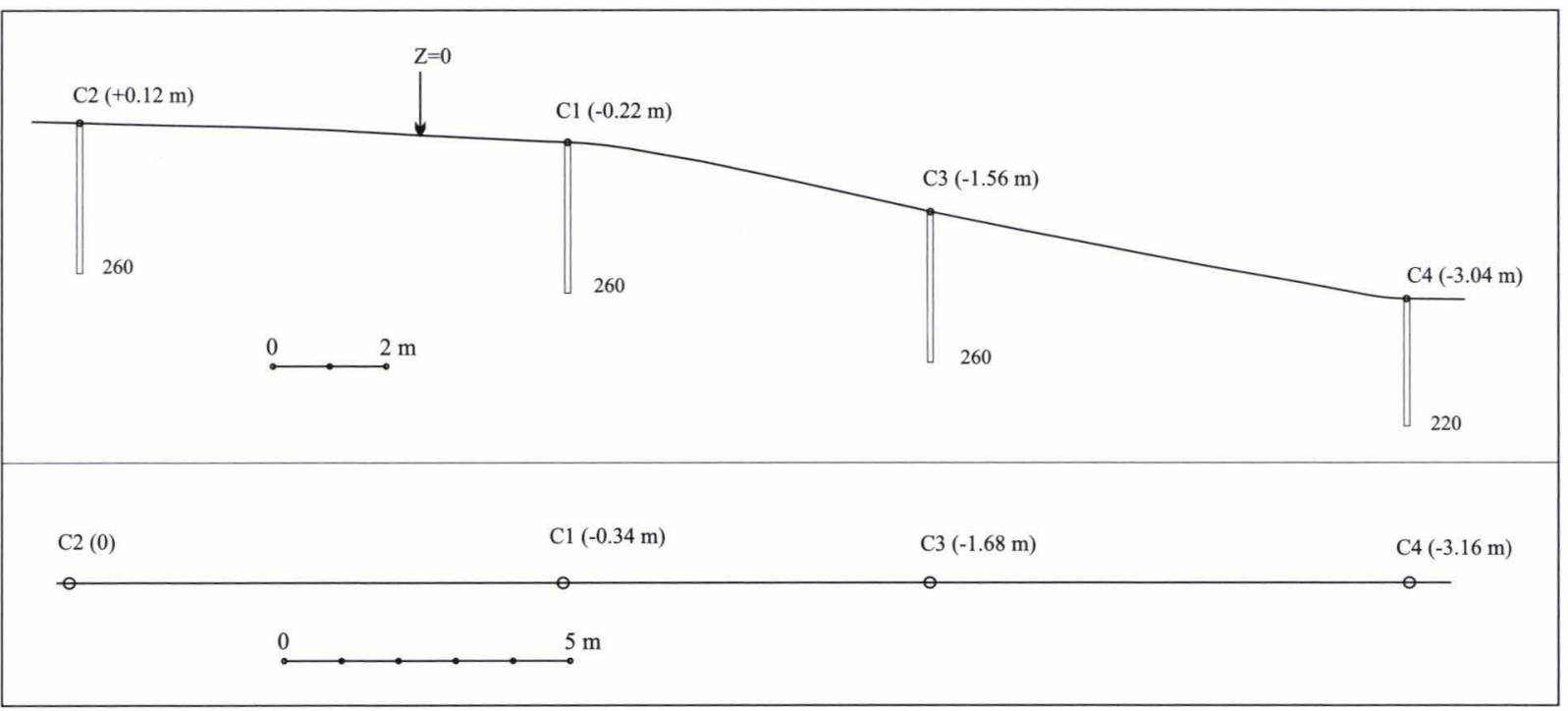

2.

1. Ridicarea topografică a tell-ului de la Vânătorii Mici Momâia și zona înconjurătoare (scanare 3D - Bogdan Venedict; cele două drepte perpendiculare marchează două dintre limitele suprafeței investigate magnetometric; scara este reprezentată de axele de coordonate Stereo 70); 2. Vânătorii Mici Momâia. Amplasamentele relative ale carotajelor stratigrafice. $1 . Z_{0}$ este reprezentat de punctul de staţie; $2 . Z_{0}$ este reprezentat de către $\mathrm{C} 2$. 

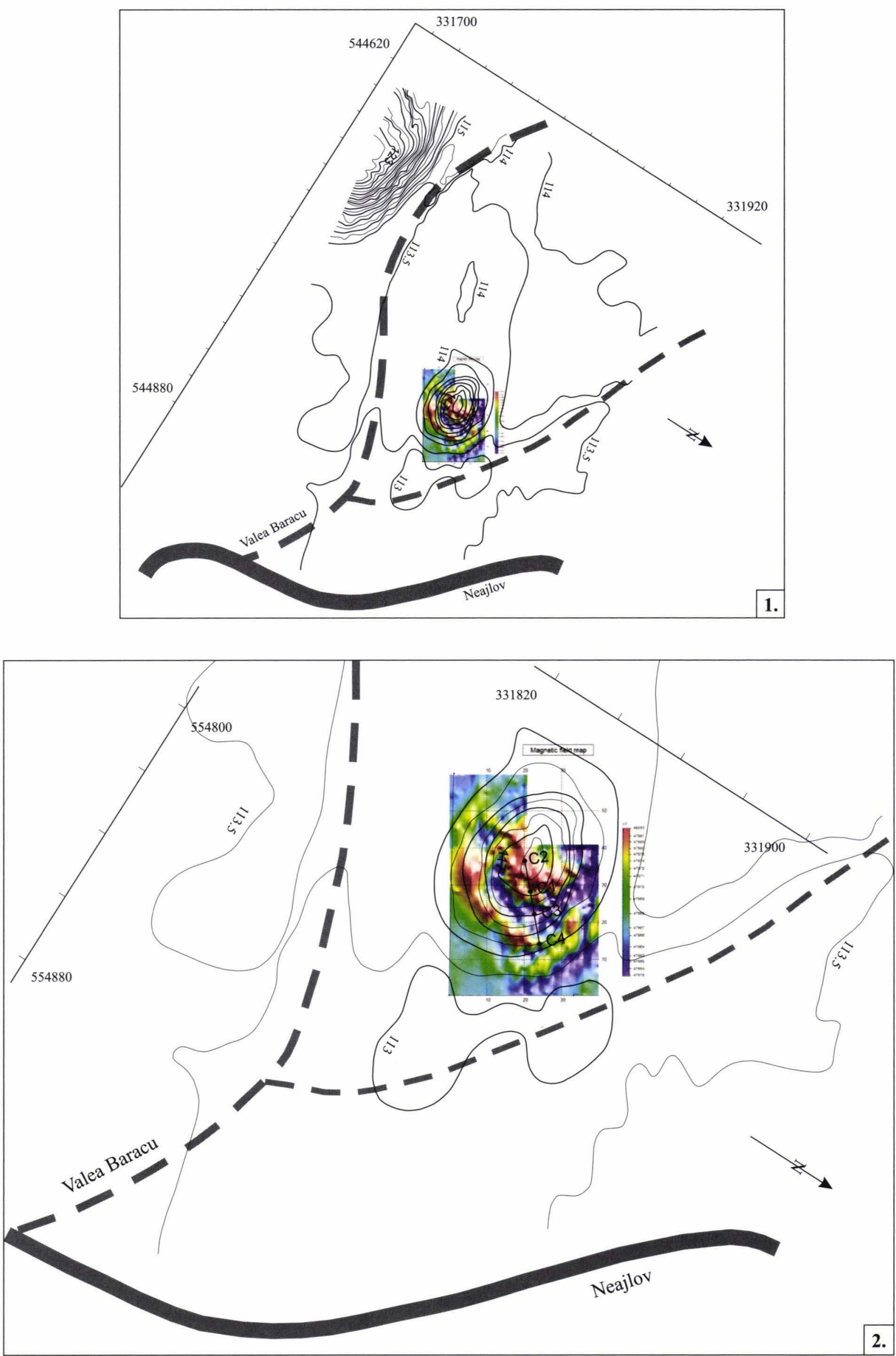

Vânătorii Mici Momâia. 1. Suprafaţa scanată magnetometric; 2. Amplasamentul carotajelor 


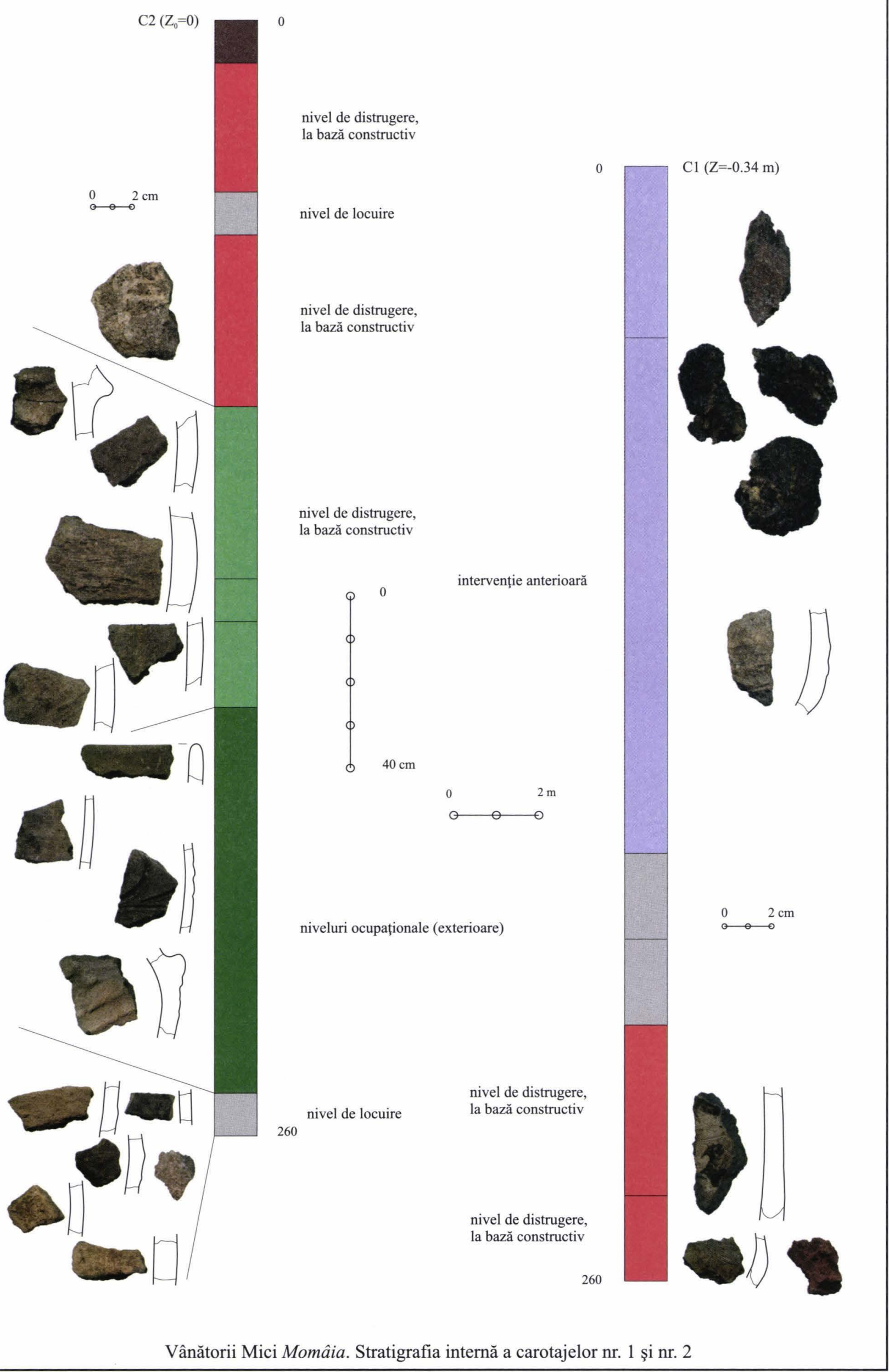




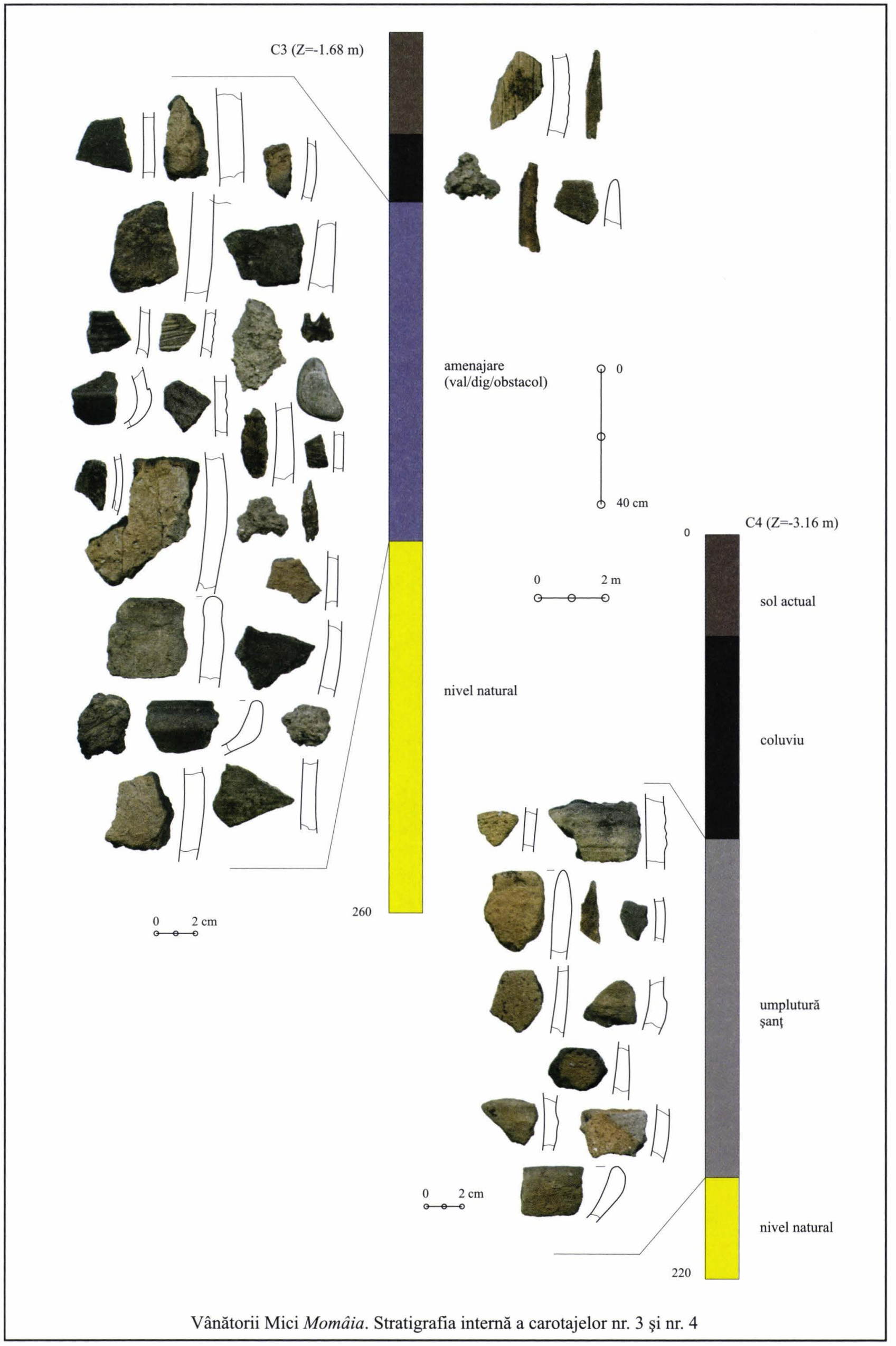

PI. VIII 


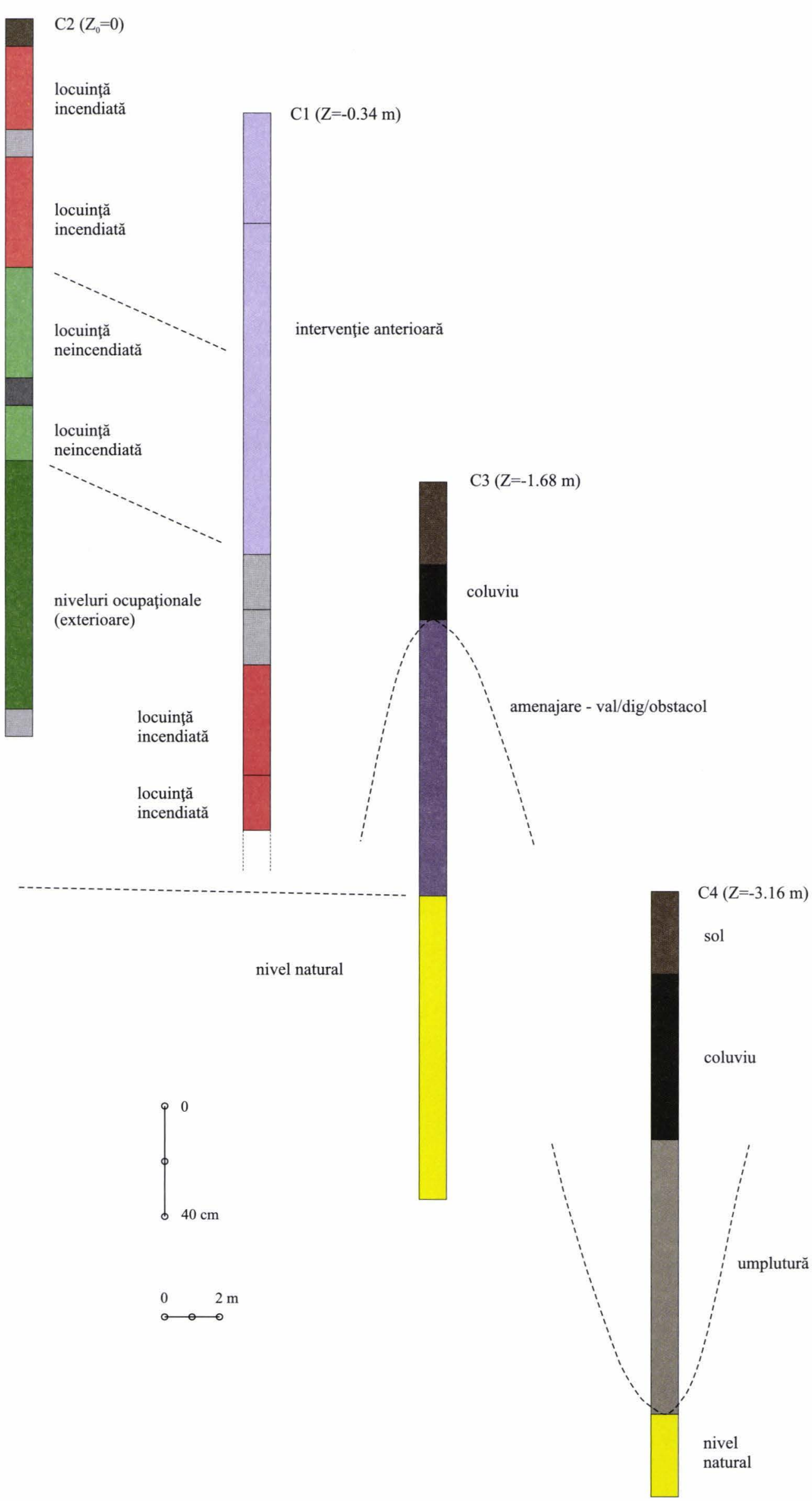

Vânătorii Mici Momâia. Schiţa stratigrafică a tell-ului relevată de cele patru carotaje.

\section{PI. IX}





6.

1-4. Vânătorii Mici Momâia. Harta magnetometrică (săgeata roşie indică amplasamentul C1, cea albastră, fostul curs de apă); 5. Planul staţiunii de la Polianiţa (apud Todorova 1982); 6. Schiţa idealizată a momentului de început al fiecărei locuiri independente dintr-un tell. 